\title{
Chemistry and transport of pollution over the Gulf of Mexico and the Pacific: spring 2006 INTEX-B campaign overview and first results
}

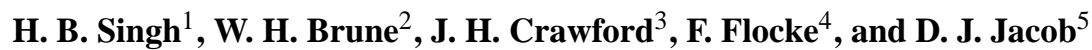 \\ ${ }^{1}$ NASA Ames Research Center, Moffett Field, CA 94035, USA \\ ${ }^{2}$ Pennsylvania State University, Dept. of Meteorology, PA 16902, USA \\ ${ }^{3}$ NASA Langley Research Center, Hampton, VA 23665, USA \\ ${ }^{4}$ National Center for Atmospheric Research, Boulder, CO 80301, USA \\ ${ }^{5}$ Harvard University, Dept. of Earth and Planetary Science, MA 02138, USA
}

Received: 30 September 2008 - Published in Atmos. Chem. Phys. Discuss.: 7 January 2009

Revised: 11 March 2009 - Accepted: 16 March 2009 - Published: 1 April 2009

\begin{abstract}
Intercontinental Chemical Transport Experiment$\mathrm{B}$ (INTEX-B) was a major NASA (Acronyms are provided in Appendix A.) led multi-partner atmospheric field campaign completed in the spring of 2006 (http://cloud1.arc.nasa.gov/intex-b/). Its major objectives aimed at (i) investigating the extent and persistence of the outflow of pollution from Mexico; (ii) understanding transport and evolution of Asian pollution and implications for air quality and climate across western North America; and (iii) validating space-borne observations of tropospheric composition. INTEX-B was performed in two phases. In its first phase (1-21 March), INTEX-B operated as part of the MILAGRO campaign with a focus on observations over Mexico and the Gulf of Mexico. In the second phase (17 April-15 May), the main INTEX-B focus was on trans-Pacific Asian pollution transport. Multiple airborne platforms carrying state of the art chemistry and radiation payloads were flown in concert with satellites and ground stations during the two phases of INTEX-B. Validation of Aura satellite instruments (TES, OMI, MLS, HIRDLS) was a key objective within INTEX-B. Satellite products along with meteorological and 3-D chemical transport model forecasts were integrated into the flight planning process to allow targeted sampling of air parcels. Inter-comparisons were performed among and between aircraft payloads to quantify the accuracy of data and to create a unified data set. Pollution plumes were sampled over the Gulf of Mexico
\end{abstract}

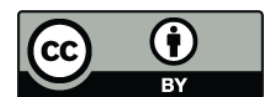

Correspondence to: H. B. Singh (hanwant.b.singh@nasa.gov) and the Pacific several days after downwind transport from source regions. Signatures of Asian pollution were routinely detected by INTEX-B aircraft, providing a valuable data set on gas and aerosol composition to test models and evaluate pathways of pollution transport and their impact on air quality and climate. This overview provides details about campaign implementation and a context within which the present and future INTEX-B/MILAGRO publications can be understood.

\section{Introduction}

Air pollution is one of the most important environmental challenges of this century. This challenge is particularly acute in the developing world where the rapid growth of megacities ( $>10$ million population) is producing atmospheric pollution of unprecedented severity and extent (Molina and Molina, 2004; Chan and Yao, 2008). In recent decades, a mounting body of atmospheric data have demonstrated that gas and aerosol emissions from major urban and industrial centers can influence both air quality and climate on scales ranging from regional to continental and global (Holloway et al., 2003; Stohl, 2004; Oltmans et al., 2006; EPA, 2007 and references there in). During the last decade, the NASA Tropospheric Chemistry Program has organized several field campaigns to investigate the outflow of pollution from Asia and North America with the goal of understanding the transport and transformation of gases and aerosols on transcontinental/intercontinental scales and their impact on air quality and climate (Hoell et al., 1996, 1997; Raper et al.,

Published by Copernicus Publications on behalf of the European Geosciences Union. 
Table 1. Principal Mobile Platforms in Operation During the Spring 2006 MILAGRO/INTEX-B Study.

\begin{tabular}{|c|c|c|c|c|c|c|}
\hline \multirow[b]{2}{*}{ Platform type ${ }^{a}$} & \multirow[b]{2}{*}{ Study name } & \multirow[b]{2}{*}{ Platforms (Country) } & \multirow[b]{2}{*}{ Dates of operation (2006) } & \multirow[b]{2}{*}{ Bases of Operation $^{b}$} & \multicolumn{2}{|c|}{ Nominal Specifications, km } \\
\hline & & & & & Altitude & Range \\
\hline Airborne & INTEX-B/MILAGRO & NASA DC- $8^{\mathrm{c}}($ USA) & 1 Mar to 15 May & HS, HI, AN & $0.2-12.5$ & 9000 \\
\hline Airborne & INTEX-B/MILAGRO & NASA/Sky Research J-31 d (USA) & 1-21 Mar & $\mathrm{VC}$ & $0.1-7.5$ & 1500 \\
\hline Airborne & INTEX-B & DLR Falcon $-20^{\mathrm{c}}$ (Germany) & $1-30 \mathrm{Apr}$ & OB & $0.1-12.8$ & 3500 \\
\hline Airborne & INTEX-B & Cessna $207^{\mathrm{c}}$ (Canada) & 22 Apr to 17 May & $\mathrm{PN}$ & $0.1-5.5$ & 800 \\
\hline Airborne & INTEX-B & UW Beechcraft Duchess $^{\mathrm{c}}$ (USA) & 1-15 May & ST & $0.1-6.0$ & 1400 \\
\hline Airborne & Mirage-MEX/INTEX-B & NSF/NCAR C- $130^{\mathrm{c}}$ (USA) & 1 Mar to 15 May & $\mathrm{VC}, \mathrm{ST}$ & $0.1-7.5$ & 6000 \\
\hline Airborne & MAX-MEX/MILAGRO & DOE G- $1^{\mathrm{c}}(\mathrm{USA})$ & 1-29 Mar & $\mathrm{VC}$ & $0.3-7.5$ & 2000 \\
\hline Airborne & MAX-MEX/MILAGRO & NASA B- $200^{\mathrm{e}}$ (USA) & 1-29 Mar & $\mathrm{VC}$ & $0.1-8.5$ & 2000 \\
\hline Spaceborne $^{\mathrm{f}}$ & Terra-NASA & Terra (MOPITT, MISR, MODIS) (USA) & continuous & LEO & all altitudes & global coverage \\
\hline Spaceborne $\mathrm{f}^{\mathrm{f}}$ & Aqua-NASA & Aqua (AIRS, MODIS) (USA) & continuous & LEO & all altitudes & global coverage \\
\hline Spaceborne $^{\mathrm{f}}$ & Aura-NASA & Aura (OMI, TES, MLS, HIRDLS) (USA) & continuous & LEO & all altitudes & global coverage \\
\hline Spaceborne $^{\mathrm{f}}$ & Envisat-ESA & Envisat (SCIAMACHY) (EU) & continuous & LEO & All altitudes & global coverage \\
\hline
\end{tabular}

a A number of fixed surface stations and sonde release sites also operated during this experiment. See Molina et al. (2008) for details.

b HS, Houston, Texas; HI, Honolulu, Hawaii; AN, Anchorage, Alaska; VC, Veracruz, Mexico; OB, Oberpfaffenhofen, Germany; ST, Seattle, Washington; PN, Pemberton, British

Columbia, Canada; LEO, Low Earth Orbit.

${ }^{\mathrm{c}}$ Extensive payload principally designed to study atmospheric composition and chemistry. DC-8 also contained two remote sensors for ozone/aerosol/Temperature.

d J-31 payload was principally designed to study aerosols, Earth surfaces, and water vapor via their effects on solar radiation.

e B-200 payload consisted of the High Spectral Resolution Lidar sensing aerosol extinction and backscatter.

${ }^{\mathrm{f}}$ Principal focus was on gas and aerosol observations in the troposphere.

2001; Jacob et al., 2003; Singh et al., 2006). INTEX-NA was a major NASA led multi-partner field campaign that focused on the inflow and outflow of pollution over the North American continent. The first phase of INTEX-NA (INTEXA) was completed in the summer of 2004 under the ICARTT umbrella and results widely disseminated (Singh et al., 2006; Fehsenfeld et al., 2006 and references there in). The second phase (INTEX-B) was completed in the spring of 2006 and forms the basis of the MILAGRO/INTEX-B Special Issue in ACP. The INTEX-B/MILAGRO effort and subsequent data analysis greatly benefited from previous campaigns over Mexico City and the Pacific (Hoell et al., 1997; Jacob et al., 2003; Parrish et al., 2004; Molina et al., 2007; Nowak et al., 2004). INTEX-B/MILAGRO was an integrated mission performed principally over Mexico, the Gulf of Mexico, and the northern Pacific Ocean during the spring of 2006 in cooperation with multiple national and international partners (Molina et al., 2008). Major objectives for INTEX-B were aimed at (i) investigating the extent and persistence of the outflow of pollution from Mexico; (ii) understanding the transport and evolution of Asian pollution and implications for air quality and climate across western North America; (iii) relating atmospheric composition to sources and sinks; (iv) characterizing the effects of aerosols on solar radiation; and (v) validating space-borne observations of tropospheric composition. This effort had a broad scope to investigate the chemistry and transport of long-lived greenhouse gases, oxidants and their precursors, aerosols and their precursors, as well their relationship with radiation and climate.

\section{Mission design and implementation}

\subsection{Measurement platforms}

The principal mobile platforms that participated in the INTEX-B/MILAGRO campaign, their bases of operation, campaign duration, and specifications are summarized in Table 1. These airborne platforms had the capability to sample much of the troposphere over long distances. Complementing these airborne platforms were several ground stations that operated during this study. An ozonesonde-radiosonde network (IONS-06) operated over 16 North American sites. Satellite observations both guided flight planning and helped to extend the range of airborne observations. Description of Mexico based platforms and ground stations focused exclusively on the MILAGRO part of the campaign are being summarized in an overview paper by Molina, L. and Madronich, S., private communication, 2009. Additional details about these platforms are available from http://cloud1.arc.nasa.gov/intex-b/ and http://www.eol.ucar.edu/projects/milagro.

\subsection{Instrument payload and measurement capability}

The payloads of a majority of airborne platforms in Table 1 were selected to measure major greenhouse gases, ozone and precursors, aerosols and precursors, and a large number of tracers. Table 2a shows the DC- 8 payload of in situ and remote sensors for measurements of both gases and aerosols. A nadir and zenith viewing UV lidar measured tropospheric $\mathrm{O}_{3}$ and aerosols remotely. A second zenith viewing lidar was tuned to stratospheric ozone and temperature measurements for HIRDLS validation. Spectral radiometers allowed direct 
Table 2a. DC-8 Science Payload During INTEX-B ${ }^{\mathrm{a}}$.

\begin{tabular}{|c|c|c|c|}
\hline Parameters & Method & Principal Investigators & $\begin{array}{l}\text { Detection Limit/Response } \\
(\text { Nominal Accuracy })^{\mathrm{b}}\end{array}$ \\
\hline $\mathrm{O}_{3}$ & $\mathrm{NO} / \mathrm{O}_{3}$ chemiluminescence & M. Avery, NASA LaRC & $1 \mathrm{ppb} / 1 \mathrm{~s}( \pm 5 \%)$ \\
\hline $\mathrm{O}_{3}$ and aerosol profile & UV DIAL lidar & E. Browell, NASA LaRC & $-/ 60 \mathrm{~s}( \pm 10 \%)$ \\
\hline $\mathrm{O}_{3}$ and temperature profile & Raman lidar & T. McGee, NASA GSFC & $-160 \mathrm{~s}( \pm 10 \%)$ \\
\hline $\begin{array}{l}\mathrm{NO}, \\
\mathrm{NO}_{2}, \mathrm{HCHO}\end{array}$ & LIF & D. Tan, Georgia Institute of Technology & $\begin{array}{l}5 \mathrm{ppt} / 60 \mathrm{~s}( \pm 10 \%) \\
15 \mathrm{ppt} / 60 \mathrm{~s}( \pm 10 \%)\end{array}$ \\
\hline $\begin{array}{l}\mathrm{NO}_{2} \\
\mathrm{NO}_{\mathrm{y}}\end{array}$ & LIF and thermal dissociation & R. Cohen, University of California, Berkeley & $\begin{array}{r}1 \mathrm{ppt} / 60 \mathrm{~s}( \pm 10 \%) \\
10 \mathrm{ppt} / 60 \mathrm{~s}( \pm 10 \%)\end{array}$ \\
\hline $\begin{array}{l}\text { PANs, } \\
\text { OVOC, nitriles }\end{array}$ & GC-ECD/PID/RGD & H. Singh, NASA ARC & $\begin{array}{r}1 \mathrm{ppt} / 90 \mathrm{~s}( \pm 15 \%) \\
10 \mathrm{ppt} / 120 \mathrm{~s}( \pm 20 \%)\end{array}$ \\
\hline $\mathrm{H}_{2} \mathrm{O}_{2}, \mathrm{CH}_{3} \mathrm{OOH}, \mathrm{HCHO}$ & derivative HPLC and fluorescence & B. Heikes, University of Rhode Island & $20 \mathrm{ppt} / 150 \mathrm{~s}( \pm 20 \%)$ \\
\hline $\mathrm{HCHO}$ & TDL absorption spectrometry & A. Fried, NCAR & $20 \mathrm{ppt} / 60 \mathrm{~s}( \pm 10 \%)$ \\
\hline $\begin{array}{l}\mathrm{OH}, \mathrm{HO}_{2} \\
\quad \text { naphthalene }\end{array}$ & LIF & W. Brune, Pennsylvania State University & $\begin{array}{r}0.02 \mathrm{ppt} / 15 \mathrm{~s}( \pm 15 \%) \\
10 \mathrm{ppt} / 15 \mathrm{~s}( \pm 15 \%)\end{array}$ \\
\hline $\mathrm{SO}_{2}, \mathrm{HNO}_{4}, \mathrm{HCl}$ & CIMS & G. Huey, Georgia Institute of Technology & $5 \mathrm{ppt} / 15 \mathrm{~s}( \pm 15 \%)$ \\
\hline NMHC, halocarbons, alkyl nitrates & whole air samples; GC-FID/EC/MS & $\begin{array}{l}\text { D. Blake, University of California, Irvine, } \\
\text { and E. Atlas, University of Miami }\end{array}$ & $1 \mathrm{ppt} / 100 \mathrm{~s}( \pm 2-10 \%)$ \\
\hline $\mathrm{CO}, \mathrm{CH}_{4}, \mathrm{~N}_{2} \mathrm{O}$ & TDL absorption spectrometry & G. Sachse, NASA LaRC & $1 \mathrm{ppb} / 5 \mathrm{~s}( \pm 5 \%)$ \\
\hline $\mathrm{CO}_{2}$ & Non-dispersive infrared analyzer & S. Vay, NASA LaRC & $0.1 \mathrm{ppm} / 1 \mathrm{~s}( \pm 0.1 \%)$ \\
\hline $\mathrm{H}_{2} \mathrm{O}$ & open path TDL absorption spectrometry & $\begin{array}{l}\text { G. Diskin, NASA LaRC, and } \\
\text { J. Podolske, NASA ARC }\end{array}$ & $5 \mathrm{ppm} / 10 \mathrm{~s}( \pm 5 \%)$ \\
\hline $\mathrm{H}_{2} \mathrm{O}, \mathrm{J}\left(\mathrm{NO}_{2}\right)$ & cryogenic hygrometer, filter radiometer & J. Barrick, NASA LaRC & $\begin{array}{l}5 \mathrm{ppm} / 10 \mathrm{~s}( \pm 10 \%) \\
10^{-6} \mathrm{~s} / 20 \mathrm{~s}( \pm 10 \%)\end{array}$ \\
\hline Bulk aerosol composition, $\mathrm{HNO}_{3}$ & Filter analysis, mist chamber/IC & J. Dibb, University of New Hampshire & $10 \mathrm{ppt} / 300 \mathrm{~s}( \pm 15 \%)$ \\
\hline TGM (Total Gaseous Mercury) & $\begin{array}{l}\text { cold vapor atomic fluorescence } \\
\text { spectrometry }\end{array}$ & R. Talbot, University of New Hampshire & \\
\hline $\begin{array}{l}\text { Aerosol number, size, composition, } \\
\text { microphysics, optical properties, } \\
\text { light absorption and scattering, cloud } \\
\text { water content }\end{array}$ & $\begin{array}{l}\text { particle spectrometers, volatility TDMA, } \\
\text { CN counters, nephelometer, soot } \\
\text { photometer, } \mathrm{f}(\mathrm{RH}) \text {, cloud and aerosol } \\
\text { probes }\end{array}$ & $\begin{array}{l}\text { A. Clarke, University of Hawaii, and B. } \\
\text { Anderson, NASA LaRC }\end{array}$ & \\
\hline $\begin{array}{l}\text { Actinic fluxes and photolytic } \\
\text { frequencies }\end{array}$ & spectral radiometery, zenith and nadir & R. Shetter, NCAR & $10^{-8} \mathrm{~s} / 15 \mathrm{~s}( \pm 5 \%)$ \\
\hline
\end{tabular}

a Instruments on board the DC-8 also measured pressure, temperature, dew point, aircraft position and orientation.

$\mathrm{b}$ These are nominal values. Detailed measurement specifications, which may vary with altitude, are provided in the headers along with data.

Table 2b. Canadian Cessna 207 Science Payload during INTEX-B ${ }^{\mathrm{a}}$.

\begin{tabular}{|c|c|c|c|}
\hline Parameters & Method & Principal Investigator & Detection Limit/ Response $^{b}$ \\
\hline Aerosol composition & $\begin{array}{l}\text { quadrupole aerosol mass } \\
\text { spectrometer (Q-AMS) }\end{array}$ & $\begin{array}{l}\text { Richard Leaitch, } \\
\text { Environment Canada (EC) }\end{array}$ & $\begin{array}{l}\mathrm{SO}_{4}^{=} \text {and } \mathrm{NO}_{3}^{-}: 40 \mathrm{ng} \mathrm{m}^{-3} / 60 \mathrm{~s} \\
\quad \text { organic: } 400 \mathrm{ng} \mathrm{m}^{-3} / 60 \mathrm{~s}\end{array}$ \\
\hline Aerosol number $>15 \mathrm{~nm}$ & $\begin{array}{l}\text { condensation particle } \\
\text { counter }\end{array}$ & Richard Leaitch, EC & $10 \mathrm{~cm}^{-3} / 1 \mathrm{~s}$ \\
\hline $\begin{array}{l}\text { Aerosol size distribution, } \\
120 \mathrm{~nm} \text { to } 2.5 \mu \mathrm{m}\end{array}$ & $\begin{array}{l}\text { optical particle counter } \\
\quad(\text { PMS PCASP-X) }\end{array}$ & Richard Leaitch, EC & $1 \mathrm{~cm}^{-3} / 1 \mathrm{~s}$ \\
\hline $\begin{array}{l}\text { Aerosol size distribution, } \\
\quad 300 \mathrm{~nm} \text { to } 20 \mu \mathrm{m}\end{array}$ & $\begin{array}{l}\text { optical particle counter } \\
\text { (PMS FSSP300) }\end{array}$ & Richard Leaitch, EC & $0.3 \mathrm{~cm}^{-3} / 1 \mathrm{~s}$ \\
\hline $\mathrm{O}_{3}$ & UV absorption & Kurt Anlauf, EC & $1 \mathrm{ppbv} / 1 \mathrm{~s}$ \\
\hline $\mathrm{CO}$ & UV resonance fluorescence & Kurt Anlauf, EC & $5 \mathrm{ppbv} / 1 \mathrm{~s}$ \\
\hline
\end{tabular}

a Other measurements include pressure, temperature, relative humidity, and aircraft position.

$\mathrm{b}$ These are nominal values. Detailed measurement specifications, which may vary with altitude, are provided in the headers along with data.

measurement of actinic flux to derive key photolysis frequencies. Multiple instruments measured physical, chemical, and optical properties of fine and coarse aerosol. The DC-8 flew $145 \mathrm{~h}$ from 1 March-15 May 2006 in 18 science/transit flights of $8-10 \mathrm{~h}$ duration from its three bases of operation (Houston, Hawaii, Anchorage). Six DC-8 sor- ties were undertaken from Houston targeted on Mexico and the Gulf of Mexico with three sorties from Hawaii and four from Anchorage targeted on Asian pollution over the $\mathrm{Pa}$ cific. The C-130 payload was similar to the in situ payload of the DC- 8 and is described in more detail in the MILAGRO overview paper by Molina, L. and Madronich, S., private 
Table 2c. UW Beechcraft Duchess 76 aircraft payload during INTEX-B (12 Apr-15 May 2006).

\begin{tabular}{llll}
\hline Measurement & Method & Detection Limit $^{\mathrm{a}}$ & Uncertainty $^{a}$ \\
\hline $\begin{array}{l}\text { Sub-micron aerosol } \\
\text { scattering }\left(\mathrm{Mm}^{-1}\right)\end{array}$ & $3 \lambda$ nephelometer (TSI Inc.) & $0.1 \mathrm{Mm}^{-1}$ & $10 \%$ \\
$\mathrm{CO}$ & vacuum UV fluorescence (AeroLaser) & $2 \mathrm{ppb}$ & $5 \%$ \\
$\mathrm{O}_{3}$ & UV absorption 2B Technologies) & $4 \mathrm{ppb}$ & $6 \%$ \\
$\mathrm{Hg}^{0}\left(\mathrm{ng} / \mathrm{m}^{3}\right)$ & $\begin{array}{c}\text { pre-concentration on Au trap w/UV fluorescence } \\
\text { Standard met and GPS }\end{array}$ & $0.1 \mathrm{ng} / \mathrm{m}^{3}$ & $10-15 \%$ \\
$\quad$ semsors & temperan, Inc.) & & \\
\hline
\end{tabular}

a These are nominal values. Detailed measurement specifications, which may vary with altitude, are provided in the headers along with data.

Table 2d. DLR Falcon science payload during INTEX-B ${ }^{\mathrm{a}}$.

\begin{tabular}{|c|c|c|c|}
\hline Parameter & Method/Instrument & Principle Investigator & Detection Limit/Response ${ }^{\mathrm{b}}$ \\
\hline $\mathrm{O}_{3}$ & UV absorption/Thermo Electron TE49 & \multirow[t]{8}{*}{ Hans Schlager, DLR } & $1 \mathrm{ppb} / 1 \mathrm{~s}$ \\
\hline $\mathrm{CO}$ & VUV fluorescence/Aerolaser AL5001 & & $5 \mathrm{ppb} / 1 \mathrm{~s}$ \\
\hline $\mathrm{CO}_{2}$ & ND IR absorption/LI-COR LI-7000 & & $0.2 \mathrm{ppm} / 1 \mathrm{~s}$ \\
\hline $\mathrm{HCHO}$ & Hantzsch synthesis/Aerolaser AL 4021 & & $50 \mathrm{ppt} / 90 \mathrm{~s}$ \\
\hline NO & chemiluminescence/modified ECO-SR & & $5 \mathrm{ppt} / 1 \mathrm{~s}$ \\
\hline $\mathrm{NO}_{\mathrm{y}}$ & $\begin{array}{l}\text { catalytic reduction+chemiluminescence/ } \\
\text { modified ECO-SR }\end{array}$ & & $20 \mathrm{ppt} / 1 \mathrm{~s}$ \\
\hline $\mathrm{NO}_{2}$ photolysis rate & filter radiometer & & $5 \mathrm{E}-4 / 1 \mathrm{~s}$ \\
\hline $\mathrm{SO}_{2}$ & $\begin{array}{l}\text { chemical ionization ion trap mass } \\
\text { spectrometer }\end{array}$ & & $20 \mathrm{ppt} / 1 \mathrm{~s}$ \\
\hline Aerosol property & Method/Instrument & Principle Investigator & Size range $(\mu \mathrm{m})^{\mathrm{b}}$ \\
\hline $\begin{array}{l}\text { Integral number } \\
\text { concentration }\end{array}$ & condensation/CPC & Andreas Petzold, DLR & $0.004-1$ \\
\hline Nano particle size & multi-channel CPC system & & $0.004-0.1$ \\
\hline Distribution & electrical mobility/DMA & & $0.01-0.2$ \\
\hline \multirow[t]{2}{*}{ Particle size distribution } & light scattering / PCASP-100X & & $0.1-3$ \\
\hline & light scattering/OPC Grimm 1.109 & & $0.25-2.5$ \\
\hline $\begin{array}{l}\text { Cloud element size } \\
\text { distribution }\end{array}$ & light scattering/FSSP-300 & & $0.4-20$ \\
\hline $\begin{array}{l}\text { Integral absorption } \\
\text { coefficient } \\
\text { (and black carbon mass) }\end{array}$ & filter transmission photometry / PSAP & & $2-100$ \\
\hline
\end{tabular}

a Other measurements include pressure, temperature, relative humidity, and aircraft position.

$\mathrm{b}$ These are nominal values. Detailed measurement specifications, which may vary with altitude, are provided in the headers along with data.

communication, 2009. The C-130 performed 13 flights over Mexico and the Gulf and undertook 11 sorties from Seattle that sampled pollution over western North America and the eastern Pacific.

An instrumented Environment Canada Cessna 207 performed some 33 short flights (approx 2-h duration) from 22 April to 17 May 2006 from a base in Western Canada in close coordination with the $\mathrm{C}-130$, and with measurements at the Whistler Peak Station $\left(50.1^{\circ} \mathrm{N}, 122.9^{\circ} \mathrm{W}, 2182 \mathrm{~m}\right)$ that has provided continuous measurements of meteorological parameters, $\mathrm{CO}$, and $\mathrm{O}_{3}$ since its establishment in 2002
(Leaitch et al., 2008). The Cessna 207 measured CO, $\mathrm{O}_{3}$, aerosol size, number density, and composition (Table 2b). A Raman lidar was operated during 11-17 May from the base of Whistler Mountain to provide profiles of aerosol backscatter in clear skies. University of Washington Beechcraft Duchess 76 performed eight flights between 12 April and 15 May 2006 out of Paine Field in Everett, Washington. The somewhat limited payload (Table 2c) included measurements of $\mathrm{CO}, \mathrm{O}_{3}, \mathrm{Hg}$, and aerosols. Complementing the airborne observations were more extensive measurements of speciated $\mathrm{Hg}$, PANs, $\mathrm{CO}, \mathrm{O}_{3}, \mathrm{NO}_{\mathrm{x}}$, and Radon 
Table 3. IONS-06 ozonesonde launch sites during INTEX-B.

\begin{tabular}{lll}
\hline Station & Lat $(\mathrm{N})$, Lon $(\mathrm{W})$ & Spring Period $(\mathrm{SN})$ \\
\hline Boulder, CO & $40.3,105.2$ & 28 Mar-18 May \\
Bratt's Lake, SAS & $50.2,104.7$ & 3 Mar-17 May \\
Egbert, ONT & $44.2,79.98$ & $8 \mathrm{Mar}-17$ May \\
Houston, TX & $29.7,95.4$ & 1 Mar-10 May \\
Huntsville, AL & $35.3,86.6$ & 1 Mar-9 May \\
Kelowna, BC & $49.9,199.4$ & 8 Mar-17 May \\
Mexico City & $19.4,98.6$ & $7-20$ Mar \\
Narragansett, RI & $41.5,71.4$ & 8 Mar-12 May \\
Richland, WA & $46.0,119.0$ & 21 Apr-15 May \\
Stonyplain, AB & $53.6,114.1$ & 8 Mar-18 May \\
Trinidad Head, CA & $40.9,124.2$ & 3 Mar-19 May \\
Table Mtn, CA & $34.4,117.7$ & 10-26 Apr \\
Valparaiso, IN & $41.5,87.0$ & 19 Apr-16 May \\
Wallops Is, VA & $37.9,75.5$ & 1 Mar-17 May \\
Walsingham, On & $42.6,80.6$ & 24 Apr-5 May \\
Yarmouth, NS & $43.9,66.1$ & 8 Mar-16 May \\
\hline
\end{tabular}

made at the Mt. Bachelor Observatory $\left(43.98^{\circ} \mathrm{N} 121.69^{\circ} \mathrm{W}\right.$; $2.7 \mathrm{~km}$ a.s.1.). The DLR Falcon-20, with a payload summarized in Table 2d, operated out of Oberpfaffenhofen, Germany and performed some 15 flights from 24 March to 3 May 2006. The objectives of the DLR Falcon flights during INTEX-B included the chemical and aerosol characterization of pollution plumes over the eastern Atlantic and Europe originating from Asia and North America. The INTEXB Ozonesonde Network Study (IONS-06) regularly launched ozonesondes from over 16 North American sites (Table 3). These launches were coordinated with the daytime Aura overpass (Thompson et al., 2008).

\subsection{Flight planning and execution}

Satellite observations, along with meteorological and chemical forecasts from global and regional chemical transport models (CTMs), were extensively used to plan, coordinate, and implement the INTEX-B field mission. Table 4 lists the major CTMs in use for planning this experiment. Meteorological products were derived from the NCEP reanalysis data. Daily meteorological and chemical forecasts guided the design and execution of the mission. Typical model products included source-tagged $\mathrm{CO}$ tracers, aerosol tracers, $\mathrm{O}_{3}$, and PAN distributions. Meteorological products included satellite imagery (visible, infrared, and water channels), precipitation and cloud fields, backward and forward trajectories, and multi-day synoptic weather forecasts. Principal satellite instruments that provided near real-time data to guide flight planning were AIRS and MOPITT (CO columns), MODIS (aerosol, fire counts), and OMI (total column $\mathrm{O}_{3}$, tropospheric $\mathrm{NO}_{2}$, absorbing aerosols). These data were combined with forward trajectories for flight planning purposes.
The NSF/NCAR C-130 coordinated activities with the DC- 8 with bases in Mexico and Seattle. This coordination was necessary to accomplish inter-comparisons among instruments, to achieve several objectives that were unattainable by a single platform, and to collect complementary data where appropriate. This also permitted quasi-Lagrangian investigations when pollution plumes sampled over Mexico and the Pacific were sampled again after several days of transport.

\subsection{Flight tracks and sampled air masses}

Figures 1 and 2a-e show flight tracks of several major airborne platforms (DC-8, C-130, Cessna-207, Beechcraft 76, Falcon-20) and their spatial coverage. Table 5a and $\mathrm{b}$ provides a brief summary of the salient flight objectives of the DC- 8 and C-130 with more details available at http://cloud1.arc.nasa.gov/intex-b/. Air masses influenced by anthropogenic pollution, forest fires, and stratosphere were sampled during INTEX-B. It was possible to fly extremely low (100 ma.g.1.) for source characterization and spiral up to $12 \mathrm{~km}$ for purposes of satellite validation. Many of the flight planning procedures used in INTEX-B were similar to INTEX-A and have been previously described (Singh et al., 2006).

\subsection{Inter-comparisons}

Intra- and inter-platform comparisons of measurements were extensively performed to establish accuracies and precisions. On the DC-8 itself, several chemical measurements were duplicated using a variety of different techniques. Salient among these were measurements of $\mathrm{O}_{3}, \mathrm{H}_{2} \mathrm{O}, \mathrm{HCHO}$, and $\mathrm{jNO}_{2}$. Inter-comparisons were also performed with other aircraft by flying in formation with a separation of less than 300 meters in the horizontal and $100 \mathrm{~m}$ in the vertical. Two to three levels were chosen between 0 and $6 \mathrm{~km}$ altitudes, and the entire inter-comparison including descent and ascent typically lasted one hour. Table 6 provides a summary of the inter-comparisons carried out by the airborne platforms, which included species such as $\mathrm{O}_{3}, \mathrm{OH}, \mathrm{HO}_{2}, \mathrm{CO}, \mathrm{SO}_{2}$, PAN, $\mathrm{NO}_{2}, \mathrm{HNO}_{3}, \mathrm{NO}_{\mathrm{y}}, \mathrm{VOC}$, and aerosol composition and properties. Comparisons were conducted in two phases: a blind phase occurring in the field shortly after completion of the flight, and a final phase after data was fully calibrated and approved by the investigators. The actual inter-comparison data and results are available at http://www-air.larc.nasa.gov/ cgi-bin/ic. While the agreement among instruments on various platforms was generally good for molecules such as $\mathrm{O}_{3}$, $\mathrm{NO}_{2}, \mathrm{CO}, \mathrm{H}_{2} \mathrm{O}, \mathrm{CO}_{2}, \mathrm{HCHO}$, and aerosol physical properties, there were large differences in measurements of $\mathrm{HO}_{\mathrm{x}}$, OVOC, $\mathrm{HNO}_{3}$, PAN, NO, and $\mathrm{H}_{2} \mathrm{O}_{2}$ that suggest a need for concerted efforts to reduce these errors. 
Table 4. Models used for flight forecasting and analysis in INTEX-B ${ }^{\mathrm{a}}$.

\begin{tabular}{|c|c|c|c|c|c|c|c|}
\hline \multicolumn{8}{|c|}{ Resolution } \\
\hline Model & Type & Horizontal & $\begin{array}{l}\text { Vertical } \\
\text { levels }\end{array}$ & $\begin{array}{l}\text { Underlying } \\
\text { Meteorological Model }\end{array}$ & Chemical Package & $\begin{array}{l}\text { Originator (Principal } \\
\text { Investigator) }\end{array}$ & $\begin{array}{l}\text { Additional } \\
\text { References }\end{array}$ \\
\hline GEOS-4 GMAO & global & $1^{\circ} \times 1.25^{\circ}$ & 55 & $\begin{array}{l}\text { GEOS-4, on-line } \\
\text { transport and clouds }\end{array}$ & tagged tracers & $\begin{array}{l}\text { I. Stajner, GMAO } \\
\text { (D. J. Jacob, Harvard) }\end{array}$ & \\
\hline GEOS-Chem & global & $2^{\circ} \times 2.5^{\circ}$ & 37 & $\begin{array}{l}\text { GEOS-4, archived } \\
\text { winds, separate } \\
\text { transport and cloud } \\
\text { algorithms }\end{array}$ & $\begin{array}{l}\text { ozone- } \mathrm{NO}_{\mathrm{x}}-\mathrm{VOC}- \\
\text { aerosol-Hg } \\
\text { chemistry }\end{array}$ & $\begin{array}{l}\text { R. Yantosca } \\
\text { (D. J. Jacob, Harvard) }\end{array}$ & Hudman et al. (2007) \\
\hline $\begin{array}{l}\text { MOZART-4- } \\
\text { NCAR }\end{array}$ & global & $2.8^{\circ} \times 2.8^{\circ}$ & 28 & $\begin{array}{l}\text { NCAR/NCEP, reanalysis } \\
\text { archived winds, }\end{array}$ & $\begin{array}{l}\text { ozone- } \mathrm{NO}_{\mathrm{x}} \text {-VOC- } \\
\text { aerosol chemistry; } \\
\text { tagged tracers }\end{array}$ & L. K. Emmons, NCAR & Pfister et al. (2005) \\
\hline RAQMS & global & $2^{\circ} \times 2.5^{\circ}$ & 36 & $\begin{array}{l}\text { NCEP GFS, isentropic } \\
\text { coordinates }\end{array}$ & $\begin{array}{l}\text { ozone-NO } \mathrm{NO}_{\mathrm{x}}-\mathrm{VOC}-\mathrm{s} \\
\text { chemistry; tagged } \\
\text { tracers }\end{array}$ & $\begin{array}{l}\text { R. B. Pierce, NASA } \\
\text { Langley }\end{array}$ & Pierce et al. (2003) \\
\hline STEM & regional & $\begin{array}{l}4 \times 4 \mathrm{~km} \text { to } 80 \\
\quad \times 80 \mathrm{~km}\end{array}$ & 21 & $\begin{array}{l}\text { RAMS-WRF-based, } \\
\text { archived winds NCEP, } \\
\text { GFS convection }\end{array}$ & $\begin{array}{l}\text { ozone- } \mathrm{NO}_{x} \text {-VOC- } \\
\text { aerosol chemistry; } \\
\text { tagged tracers }\end{array}$ & $\begin{array}{l}\text { G. R. Carmichael, } \\
\text { University of Iowa }\end{array}$ & Tang et al. (2004) \\
\hline FLEXPART & global & Lagrangian & & NCEP GFS winds & tagged tracers & A. Stohl, NILU & Stohl et al. (1998) \\
\hline $\begin{array}{l}\text { Photochemical } \\
\text { model/LaRC }\end{array}$ & $\begin{array}{c}\text { 0-d "box" } \\
\text { model }\end{array}$ & $\ldots$ & $\cdots$ & & $\begin{array}{l}\text { ozone- } \mathrm{NO}_{\mathrm{x}} \text {-VOC- } \\
\text { chemistry }\end{array}$ & $\begin{array}{l}\text { J. H. Crawford, NASA } \\
\text { Langley }\end{array}$ & Olson et al. (2004) \\
\hline
\end{tabular}

${ }^{\text {a }}$ Flight planning process also used weather forecasts and FLEXPART trajectories based on NCEP analysis and near real-time satellite data from AIRS and MOPITT (CO columns), MODIS (aerosol, fire counts), OMI ( $\mathrm{NO}_{2}$ ), TOMS (tropospheric ozone, and absorbing aerosols), and LIS (lightning). Potential vorticity and convective influence plots were also available.

Table 5a. INTEX-B DC-8 missions and salient activity ${ }^{\mathrm{a}}$.

\begin{tabular}{|c|c|c|c|c|}
\hline Flight & Date & Operational Base ${ }^{b}$ & Flight Hours & Salient Mission Activity \\
\hline 3 & 4 Mar 2006 & Houston, Texas & 6.1 & $\begin{array}{l}\text { Sampling of outflow from south Eastern US along the satellite tracks, validation of Aura satellite } \\
\text { instruments (TES and OMI), as well as Aqua and Envisat. }\end{array}$ \\
\hline 4 & 9 Mar 2006 & Houston, Texas & 8.4 & $\begin{array}{l}\text { Sampling of outflow from Mexico City to the Gulf of Mexico, coordination with C-130 to investigate the } \\
\text { aging of the Mexico City pollution, validation of Aura satellite instruments (TES and OMI), as well as Envisat. }\end{array}$ \\
\hline 5 & 11 Mar 2006 & Houston, Texas & 7.4 & $\begin{array}{l}\text { sampling of the aged Mexico City plume previously sampled by the C- } 130 \text { near Mexico City on } 3 / 10 \text {, } \\
\text { Sampling the Mexico City boundary layer both remotely (DIAL) and in situ as initial conditions for a } \\
\text { C-130 flight on } 3 / 12 \text {. }\end{array}$ \\
\hline 6 & 12 Mar 2006 & Houston, Texas & 7.8 & $\begin{array}{l}\text { Validation of Aura satellite instruments (TES and OMI), inter-comparison with the NSF/NCAR C-130, } \\
\text { sampling of aged Mexico City pollution outflow and its near source characterization using both remote } \\
\text { (DIAL) and in situ measurements. }\end{array}$ \\
\hline 7 & 16 Mar 2006 & Houston, Texas & 7.1 & $\begin{array}{l}\text { Sampling of aged pollution and plume scouting for the C-130 north of Mexico City, sampling fresh Mexico City } \\
\text { pollution during weekday conditions, sampling convective outflow over the southern Gulf of Mexico, } \\
\text { and satellite validation (TES, OMI, and AIRS) that included a profile under TES at the time of } \\
\text { overpass followed by in-progress profiling along the TES special observation track. }\end{array}$ \\
\hline 8 & 19 Mar 2006 & Houston, Texas & 6.5 & $\begin{array}{l}\text { Inter-comparison with the NSF/NCAR C-130, coordinated spiral with the J-31, validation of the Aura } \\
\text { satellite instruments (TES and OMI), sampling of aged Mexico City pollution outflow, and the near } \\
\text { source characterization of Mexico City an Monterrey pollution. }\end{array}$ \\
\hline 9 & 22 Mar 2006 & $\begin{array}{l}\text { Houston, Texas to NASA Ames Research } \\
\text { Center (ARC) }\end{array}$ & 7.4 & $\begin{array}{l}\text { Validation of HIRDLS observations in the stratosphere and upper troposphere using the DC- } 8 \text { AROTAL } \\
\text { Lidar as the primary instrument. }\end{array}$ \\
\hline 10 & 17 Apr 2006 & NASA ARC to Honolulu, Hawaii & 9.0 & $\begin{array}{l}\text { Inter-comparison with the C-130, sampling of aged and fresh Asian pollution over the Pacific, and } \\
\text { validation of TES and OMI observations. }\end{array}$ \\
\hline 11 & 23 Apr 2006 & Honolulu, Hawaii & 8.3 & Sampling of aged and fresh Asian pollution over the Pacific and validation of TES and OMI observations. \\
\hline 12 & 25 Apr 2006 & Honolulu, Hawaii & 8.9 & Sampling of aged and fresh Asian pollution over the Pacific and validation of MLS and TES observations. \\
\hline 13 & 28 Apr 2006 & Honolulu, Hawaii & 8.1 & $\begin{array}{l}\text { Sampling Asian pollution to the west of Hawaii, providing validation data for TES with two spirals along } \\
\text { the orbit track. }\end{array}$ \\
\hline 14 & 1 May 2006 & Honolulu, Hawaii to Anchorage, Alaska & 9.2 & $\begin{array}{l}\text { Extensive validation of the HIRDLS instrument aboard the Aura satellite, sampling Asian pollution, TES } \\
\text { Validation, inter-comparisons with instrumentation at the Mauna Loa observatory, specialized channel } \\
\text { run targeted to study air-sea exchange processes. }\end{array}$ \\
\hline 15 & 4 May 2006 & Anchorage, Alaska & 7.7 & $\begin{array}{l}\text { validation for OMI especially behind a front, performing clear air sampling of Arctic air and recent Asian } \\
\text { pollution, setting up coordination with the C- } 130 \text { on 5/5. }\end{array}$ \\
\hline 16 & 7 May 2006 & Anchorage, Alaska & 8.0 & $\begin{array}{l}\text { Validation for MLS and TES along the limb track, vertical profiling through Asian plumes, setting up } \\
\text { coordination for C-130 sampling the following day. }\end{array}$ \\
\hline 17 & 9 May 2006 & Anchorage, Alaska & 8.4 & Providing validation for TES along its limb and nadir tracks, and vertical profiling through Asian plumes. \\
\hline 18 & 12 May 2006 & Anchorage, Alaska & 9.2 & $\begin{array}{l}\text { Sampling Asian pollution both ahead and behind the ridge associated with a large WCB, boundary } \\
\text { sampling of the Bethel wetlands, validation spiral for TES. }\end{array}$ \\
\hline 19 & 15 May 2006 & $\begin{array}{l}\text { Anchorage, Alaska to Grand Forks, } \\
\text { North Dakota }\end{array}$ & 8.8 & $\begin{array}{l}\text { Inter-comparison with the } \mathrm{C}-130 \text {, spiral with the Duchess, boundary layer leg over Montana in the OMI } \\
\text { view to seek apparent } \mathrm{NO}_{2} \text { hotspots, interception of plumes of Asian outflow. }\end{array}$ \\
\hline
\end{tabular}

a More details on individual flights can be found at http://www-air.larc.nasa.gov/missions/intex-b/INTEX_B_Flight_times_DC8.htm

${ }^{\mathrm{b}}$ Houston, Texas, $29.6^{\circ} \mathrm{N}, 95.1^{\circ} \mathrm{W}$; NASA ARC,

$37.4^{\circ} \mathrm{N}, 122.0^{\circ} \mathrm{W}$; Honolulu, Hawaii, $21.3^{\circ} \mathrm{N}$,

$157.9^{\circ} \mathrm{W}$; Anchorage, Alaska, $61.2^{\circ} \mathrm{N}, 150.1^{\circ} \mathrm{W}$; Grand

Forks, North Dakota, $47.9^{\circ} \mathrm{N}, 97.4^{\circ} \mathrm{W}$. 

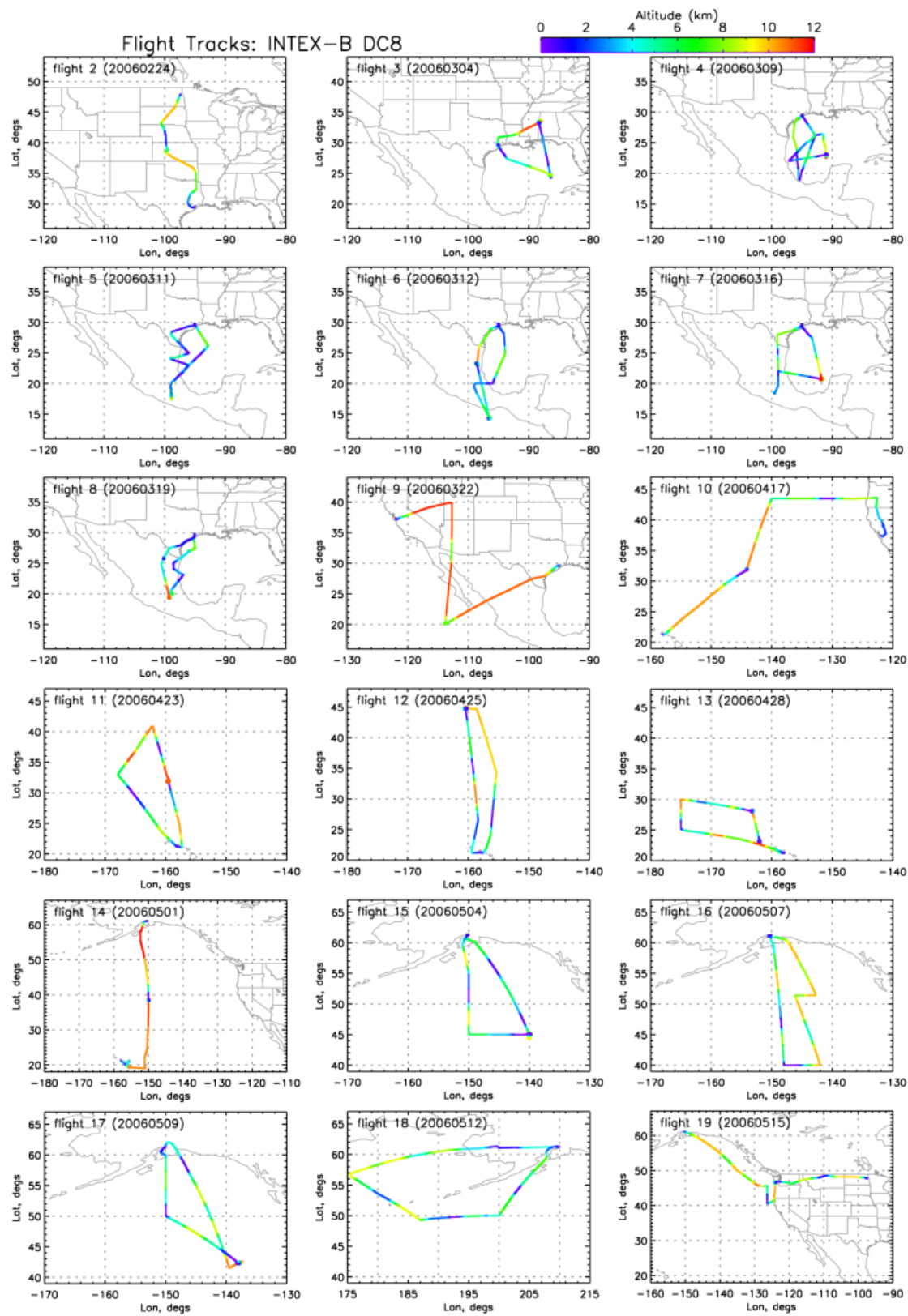

Fig. 1. DC-8 individual flight tracks in INTEX-B colored by altitude. 17 science flights were performed from 4 March to 15 May, 2008.

Specific details on the inter-comparison results will be published in a forthcoming paper to the MILAGRO/INTEXB Special Issue by Chen et al., private communication, 2009.

\subsection{Satellite validation}

Satellite sensors measure radiances from which information on atmospheric composition is retrieved using radiative transfer algorithms with substantial and often poorly characterized uncertainties. Validation of satellite derived tropospheric composition and optical properties were a pri- mary goal and received a great deal of attention from the NASA DC-8, J-31, and to a lesser extent, the C130 platforms. The principal focus of INTEX-B was on the Aura satellite (Schoeberl et al., 2006), but validation studies for SCIAMACHY/Envisat, MODIS-Terra/Aqua, and MISR/Terra were also carried out (Table 7a, b). The DC-8 focused on several trace gases $\left(\mathrm{O}_{3}, \mathrm{CO}, \mathrm{NO}_{2}, \mathrm{HNO}_{3}\right.$, and $\mathrm{HCHO}$ ) and together with the J-31 on aerosols and clouds.

Opportunities to under-fly satellites for integrated science and validation were examined and planned for each flight. 
Table 5b. INTEX-B C-130 missions and salient activity ${ }^{a}$

\begin{tabular}{|c|c|c|c|c|}
\hline Flight & Date & Operational Base ${ }^{b}$ & Flight Hours & Salient Mission Activity \\
\hline 1 & 17 Apr 2006 & $\begin{array}{l}\text { Boulder, Colorado } \\
\text { to Seattle, Washington }\end{array}$ & 8.7 & Intercomparison with DC-8. \\
\hline 2 & 21 Apr 2006 & Seattle, Washington & 7.7 & Sampling of Asian pollution off the US coast. \\
\hline 3 & 24 Apr 2006 & Seattle, Washington & 5.3 & $\begin{array}{l}\text { Sampling of local Seattle pollution at low altitude and possible Asian pollution in free troposphere; } \\
\text { flyby comparison with Mt. Bachelor site. }\end{array}$ \\
\hline 4 & 26 Apr 2006 & Seattle, Washington & 7.6 & Sampling Asian pollution around frontal system off the US coast. \\
\hline 5 & 28 Apr 2006 & Seattle, Washington & 7.9 & Sampling of Asian pollution off the US coast and OMI validation profile. \\
\hline 6 & 1 May 2006 & Seattle, Washington & 7.7 & Sampling of Asian pollution at high altitude and Terra validation profile. \\
\hline 7 & 3 May 2006 & Seattle, Washington & 8.5 & $\begin{array}{l}\text { Sampling of Asian pollution aloft and local pollution in California's central valley, intercomparison with } \\
\text { Canadian Cessna and ground site at Whistler peak, flyby comparison with Mt. Bachelor site, and OMI } \\
\text { spiral near Fresno followed by extended BL sampling for OMI from Fresno to Bakersfield. }\end{array}$ \\
\hline 8 & 5 May 2006 & Seattle, Washington & 8.5 & Sampling of Asian pollution off the US coast and one day downwind of previous encounter by DC- 8 . \\
\hline 9 & 8 May 2006 & Seattle, Washington & 8.2 & $\begin{array}{l}\text { Sampling of Asian pollution over land and water and California pollution at two times of day, } \\
\text { flyby comparison with the Mt. Bachelor site, NO2 spirals coincident with SCIAMACHY and OMI } \\
\text { overpasses at the same location near Sacramento. }\end{array}$ \\
\hline 10 & 9 May 2006 & Seattle, Washington & 7.5 & $\begin{array}{l}\text { Sampling of Asian pollution over the northwestern US, intercomparison with UW Duchess and NATIVE } \\
\text { trailer/sounding in Richland, WA. }\end{array}$ \\
\hline 11 & 11 May 2006 & Seattle, Washington & 7.8 & $\begin{array}{l}\text { Sampling of low altitude Asian pollution over land and water, NO2 spirals under SCIAMACHY and OMI } \\
\text { overpasses. }\end{array}$ \\
\hline 12 & 15 May 2006 & $\begin{array}{l}\text { Seattle, Washington } \\
\text { to Boulder, Colorado }\end{array}$ & 6.8 & Intercomparison with DC-8 and sampling of Asian pollution further inland. \\
\hline
\end{tabular}

${ }^{a}$ More details on individual flights can be found at http://cloud1.arc.nasa.gov/intex-b/flightplanningC130.cgi.

$\mathrm{b}$ Boulder, Colorado, $40.0^{\circ} \mathrm{N}, 105.3^{\circ} \mathrm{W}$; Seattle, Washington, $47.6^{\circ} \mathrm{N}, 122.3^{\circ} \mathrm{W}$.

Table 6. Principal DC-8 airborne intercomparisons.

\begin{tabular}{lllll}
\hline Intercomparing Platforms & Dates (2006) & Approximate Location & Time, UT & Level Altitude Legs, km \\
\hline DC-8 and C-130 & $19 \mathrm{Mar}$ & $22^{\circ} \mathrm{N}, 98^{\circ} \mathrm{W}$ & $18: 34-19: 12$ & $0.6,2.6$ \\
DC-8 and J-31 & $19 \mathrm{Mar}$ & $20^{\circ} \mathrm{N}, 99^{\circ} \mathrm{W}$ & $19: 17-19: 27$ & spiral \\
DC-8 and C-130 & $17 \mathrm{Apr}$ & $43^{\circ} \mathrm{N}, 122^{\circ} \mathrm{W}$ & $18: 03-18: 48$ & $3.7,6.1$ \\
DC-8 and C-130 & $15 \mathrm{May}$ & $43^{\circ} \mathrm{N}, 126^{\circ} \mathrm{W}$ & $18: 18-19: 23$ & $5.2,1.6,0.3$ \\
DC-8 and Beechcraft Duchess & $15 \mathrm{May}$ & $47^{\circ} \mathrm{N}, 124^{\circ} \mathrm{W}$ & $20: 32-21: 03$ & 5.3, spiral \\
\hline
\end{tabular}

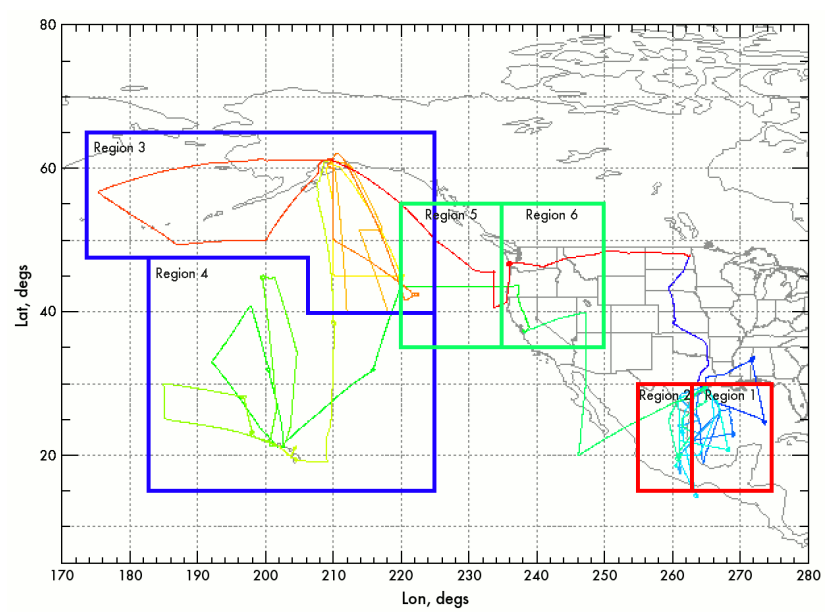

Fig. 2a. Composite of DC-8 flight tracks during INTEX-B. Boxes indicate select regions subjected to data analysis.

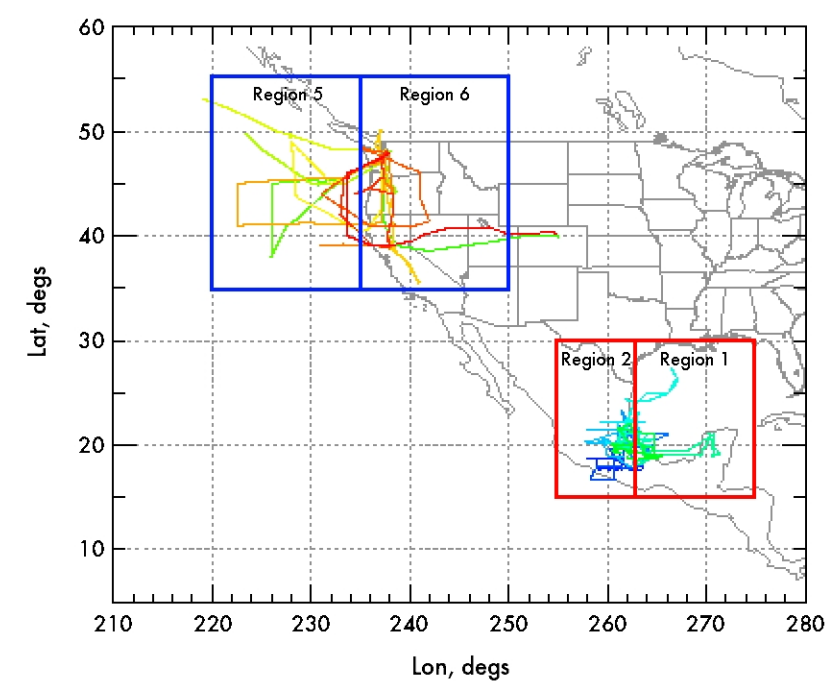

Fig. 2b. Composite of C-130 flight tracks during MILAGRO/INTEX-B 
Table 7a. Satellite measurements targeted for validation in INTEX-B.

\begin{tabular}{llll}
\hline Satellite Instruments & Platform (Launch Date) & Validation Measurements & More Information \\
\hline MISR & Terra (Dec 1999) & aerosol & http://terra.nasa.gov/About/MISR/index.php \\
MODIS & Terra (Dec 1999) & aerosol, $\mathrm{H}_{2} \mathrm{O}$ & $\mathrm{http} / /$ terra.nasa.gov/About/MODIS/index.php \\
MOPITT & Terra (Dec 1999) & $\mathrm{CO}$ & $\mathrm{http} / /$ terra.nasa.gov/About/MOPITT/index.php \\
AIRS & Aqua (May 2002) & $\mathrm{CO}, \mathrm{H}_{2} \mathrm{O}$ & $\mathrm{http} / /$ aqua.nasa.gov/about/instrument_airs.php \\
MODIS & Aqua (May 2002) & aerosol, $\mathrm{H}_{2} \mathrm{O}$ & $\mathrm{http} / /$ aqua.nasa.gov/about/instrument_modis_science.php \\
SCIAMACHY & Envisat (Mar 2002) & $\mathrm{NO}_{2}, \mathrm{HCHO}$ & $\mathrm{http} / / /$ ww.iup.physik.uni-bremen.de/sciamachy/ \\
TES & Aura (Jul 2004) & $\mathrm{O}_{3}, \mathrm{CO}, \mathrm{CH}_{4}$ & $\mathrm{http} / /$ aura.gsfc.nasa.gov/ \\
MLS & Aura (Jul 2004) & $\mathrm{O}_{3}, \mathrm{CO}, \mathrm{HNO}_{3}$ & $\mathrm{http://aura.gsfc.nasa.gov/}$ \\
OMI & Aura (Jul 2004) & $\mathrm{NO}_{\mathrm{x}}, \mathrm{HCHO}, \mathrm{SO}_{2}$ & $\mathrm{http} / / /$ aura.gsfc.nasa.gov/ \\
HIRDLS & Aura (Jul 2004) & $\mathrm{O}_{3}, \mathrm{CO}($ stratospheric) & $\mathrm{http} / / /$ aura.gsfc.nasa.gov/ \\
\hline
\end{tabular}

Table 7b. DC-8 satellite validation opportunities during INTEX-B

\begin{tabular}{lllll}
\hline Instrument & Flight & Dates $(2006)$ & Approximate Location & Time, UT \\
\hline TES/OMI/AIRS & 3 & $4 \mathrm{Mar}$ & $33^{\circ} \mathrm{N} ; 88^{\circ} \mathrm{W}$ & $17: 54-18: 25$ \\
TES/OMI/AIRS/SCIAMACHY & 3 & $4 \mathrm{Mar}$ & $24^{\circ} \mathrm{N} ; 86^{\circ} \mathrm{W}$ & $20: 16-20: 50$ \\
TES/OMI/SCIAMACHY & 4 & $9 \mathrm{Mar}$ & $23^{\circ} \mathrm{N} ; 91^{\circ} \mathrm{W}$ & $19: 25-19: 58$ \\
TES/OMI & 6 & $12 \mathrm{Mar}$ & $14-23^{\circ} \mathrm{N} ; 97-99^{\circ} \mathrm{W}$ & $18: 37-21: 07$ \\
TES/OMI/AIRS & 7 & $16 \mathrm{Mar}$ & $20-28^{\circ} \mathrm{N} ; 92-94^{\circ} \mathrm{W}$ & $19: 14-21: 19$ \\
TES/OMI & 8 & $19 \mathrm{Mar}$ & $19-25^{\circ} \mathrm{N} ; 99-101^{\circ} \mathrm{W}$ & $19: 42-21: 15$ \\
HIRDLS & 9 & $22 \mathrm{Mar}$ & $20-40^{\circ} \mathrm{N} ; 113-114^{\circ} \mathrm{W}$ & $06: 19-09: 46$ \\
TES/OMI & 10 & $17 \mathrm{Apr}$ & $32^{\circ} \mathrm{N} ; 144^{\circ} \mathrm{W}$ & $22: 52-23: 19$ \\
TES/OMI & 11 & $23 \mathrm{Apr}$ & $25-40^{\circ} \mathrm{N} ; 158-162^{\circ} \mathrm{W}$ & $22: 25-01: 55$ \\
MLS & 12 & $25 \mathrm{Apr}$ & $34-45^{\circ} \mathrm{N} ; 155-156^{\circ} \mathrm{W}$ & $21: 50-23: 18$ \\
TES/OMI & 12 & $25 \mathrm{Apr}$ & $45^{\circ} \mathrm{N} ; 160^{\circ} \mathrm{W}$ & $23: 41-00: 07$ \\
TES/OMI & 13 & $28 \mathrm{Apr}$ & $23-28^{\circ} \mathrm{N} ; 162-163^{\circ} \mathrm{W}$ & $22: 32-00: 27$ \\
TES/HIRDLS & 14 & $1 \mathrm{May}$ & $19-55^{\circ} \mathrm{N} ; 150-152^{\circ} \mathrm{W}$ & $07: 51-13: 27$ \\
OMI & 15 & $4 \mathrm{May}$ & $44^{\circ} \mathrm{N} ; 139^{\circ} \mathrm{W}$ & $22: 44-22: 48$ \\
MLS & 16 & $7 \mathrm{May}$ & $51-59^{\circ} \mathrm{N} ; 144-147^{\circ} \mathrm{W}$ & $21: 00-22: 16$ \\
TES & 16 & $7 \mathrm{May}$ & $40-50^{\circ} \mathrm{N} ; 142-146^{\circ} \mathrm{W}$ & $22: 38-00: 08$ \\
TES & 17 & $9 \mathrm{May}$ & $42-61^{\circ} \mathrm{N} ; 139-159^{\circ} \mathrm{W}$ & $19: 57-23: 21$ \\
TES/OMI & 17 & $9 \mathrm{May}$ & $42^{\circ} \mathrm{N} ; 137^{\circ} \mathrm{W}$ & $23: 45-00: 14$ \\
TES/OMI & 18 & $12 \mathrm{May}$ & $49^{\circ} \mathrm{N} ; 173^{\circ} \mathrm{W}$ & $00: 16-00: 46$ \\
\hline
\end{tabular}

Validations were performed to test retrievals with a variety of underlying surfaces. A typical DC-8 validation flight for nadir viewing instruments (e.g. OMI, TES) involved a profile from 0.2 to $11.5 \mathrm{~km}$, spiraling with a $20 \mathrm{~km}$ radius within \pm 30 min of the satellite overpass time under relatively cloud free conditions. Limb viewing instruments (e.g. MLS) frequently required sampling along the satellite track utilizing both in situ and remote sensing capabilities on the DC8. Two flights were dedicated to validation of HIRDLS $\mathrm{O}_{3}$ and temperature in the stratosphere using the AROTAL lidar, which required night flights for observations to reach maximum altitudes. In all cases, the DC- 8 provided important chemical and physical data that could be used to improve satellite retrievals. While satellite under-flights were usually planned to focus on a specific satellite instrument, the prox- imity of A-Train observations and wide swaths for some instruments allowed these flights to routinely benefit multiple satellite sensors.

\section{Overview of first results}

We provide here a brief overview of the INTEX-B results presented in the first collection of papers assembled in this Special Issue of Atmospheric Chemistry and Physics and published elsewhere to date. We focus principally on the $\mathrm{Pa}-$ cific component assessing the influence of transpacific transport. Additional information on the INTEX-B/MILAGRO mission is available from Molina et al. (2008) and a complementary overview paper that focuses on activities from platforms based within Mexico is in preparation (Molina, L. and 

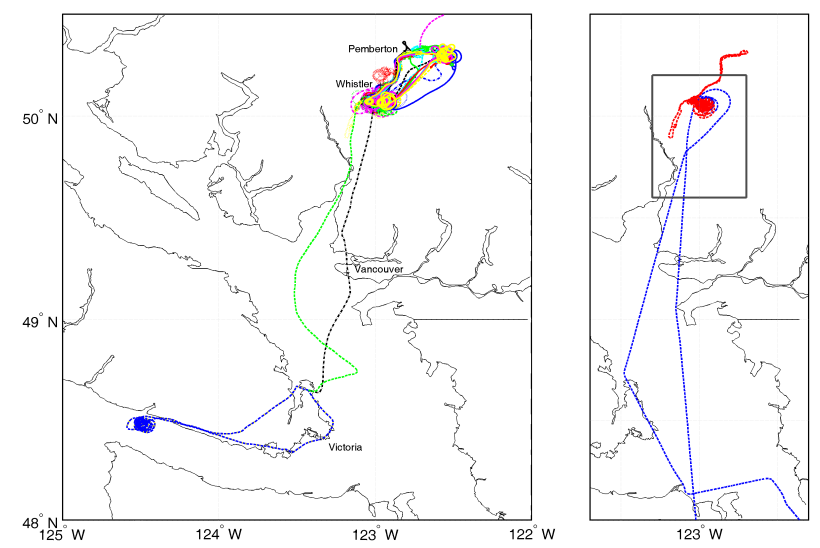

Fig. 2c. Flight paths of the Cessna 207 aircraft during the INTEX-B campaign over 22 April to 17 May, 2006. Colors represent individual flights.

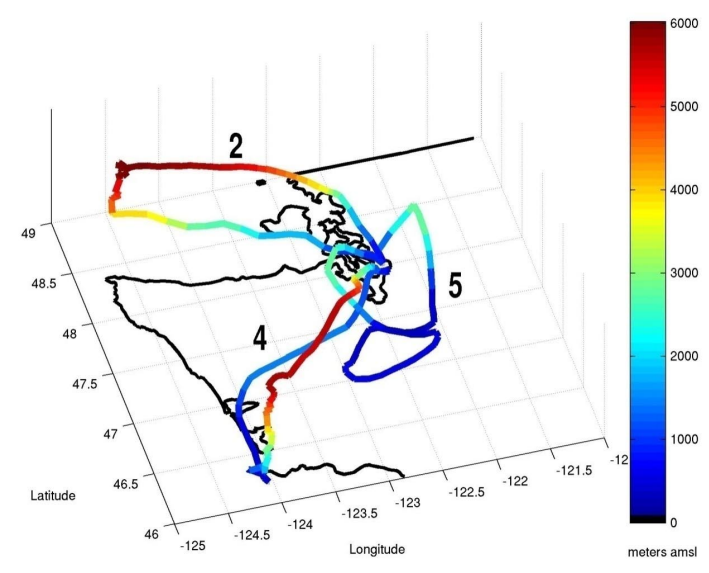

Fig. 2d. Sample flight tracks of the U. of Washington Beechcraft Duchess colored by altitude. Three representative flights are shown; flight 2 (18 April 2006), flight 4 (30 April 2006) and flight 5 (4 May 2006).

Madronich, S., private communication, 2009). In the following sections we briefly discuss results based on (1) integrated analysis of data using observations and models; (2) chemistry and transport model evaluation; and (3) satellite validation results and analysis from satellite observations. The reader is referred to the specific papers for more information. We also note that the data continue to be further analyzed and new results are anticipated.

\subsection{Pollution transport and chemistry: integrated anal- ysis of data}

Many studies being published in the ACP Special Issue analyzed observed data from aircraft, ground stations, and satellites with the help of models. Here we briefly discuss

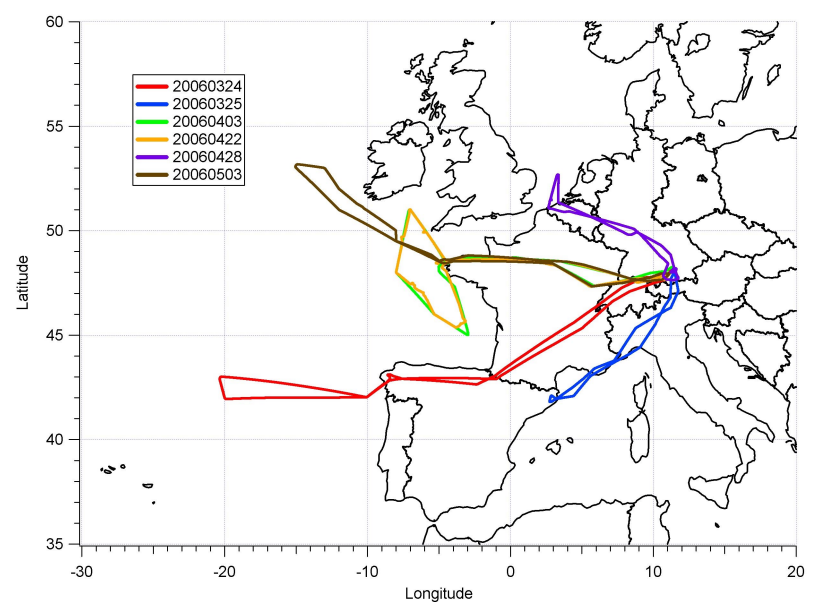

Fig. 2e. Flight paths of the DLR Falcon-20 during INTEX-B

INTEX-B papers that have been submitted for publication. At this point a majority of the studies are focused on the $\mathrm{Pa}$ cific component of INTEX-B.

\subsubsection{Airborne observations and trans-pacific transport}

There was extensive evidence for pollution transport from Asia to North America and all the way to Europe. Concurrent satellite CO and ozone observations (TES, AIRS, MOPITT) showed direct evidence for trans-Pacific pollution transport (Molina et al., 2008; Zhang et al., 2008). Fiedler et al. (private communication, 2008) intercepted pollution plumes transported all the way from Asia to the eastern Atlantic and investigated the $\mathrm{SO}_{2}$ induced aerosol formation in these plumes. Zhang et al. (2009) developed a new inventory of Asian emissions to support INTEX-B and find an increasing trend during 2001-2006: $36 \%$ increase for $\mathrm{SO}_{2}, 55 \%$ for $\mathrm{NO}_{\mathrm{x}}, 18 \%$ for $\mathrm{CO}, 29 \%$ for VOC, $13 \%$ for $\mathrm{PM}_{10}$, and $14 \%$ for $\mathrm{PM}_{2.5}$, BC, and OC. Zhang et al. (2008) interpret INTEX-B and satellite observations to investigate the transport and evolution of pollution over the Pacific and its impact on surface air quality over western North America. Satellite derived tropospheric columns of $\mathrm{NO}_{2}$ indicate an increase of some 8-10\%/year from 2000-2006 over China consistent with the bottom-up results of Zhang et al. (2009). The semi-permanent Pacific High and Aleutian Low cause splitting of trans-Pacific pollution plumes over the northeast Pacific. Both aircraft measurements and model results showed sustained ozone production driven by PAN decomposition in the southern branch, adding to ozone produced in the Asian continental boundary layer. Model simulation of ozone observations suggest that Asian pollution in spring 2006 enhanced surface $\mathrm{O}_{3}$ concentrations by $5-7 \mathrm{ppb}$ over western North America. Modeled sensitivities of Pacific tropospheric $\mathrm{O}_{3}$ columns to Asian anthropogenic emissions and lightning are $>3.7 \mathrm{DU}$ and $>2.1 \mathrm{DU}$, respectively. 

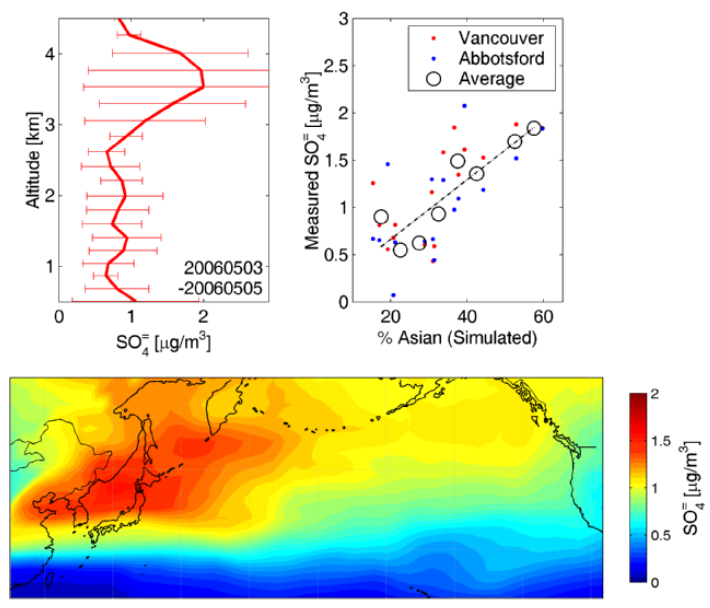

Fig. 3. Transpacific transport of sulfate. The top left panel shows average Cessna Q-AMS measured sulfate over Whistler, British Columbia during 3-5 May, 2006. The top right panel shows surface filter pack measurements of sulfate from Canada's National Air Pollution Network versus simulated East Asian sulfate fraction during April-May 2006. Black circles denote 5\% binned averages. Bottom panel shows simulated mean sulfate concentrations over AprilMay 2006 at $3.5 \mathrm{~km}$ from the GEOS-Chem model. Adapted from van Donkelaar et al. (2008).

INTEX-B data over the Pacific clearly showed that a dominant fraction of reactive nitrogen was in the form of transported PAN. Wolfe et al. (2007) utilize observations of PANs at the MBO to conclude that trans-Pacific transport of Asian pollution leads to substantial increases in PANs and ozone at this site. The ensemble of trajectories indicates that Asian-influenced free tropospheric air contained a median PAN mixing ratio double that of the full dataset. Zhang et al. (2008) use observations and 3-D models to elucidate the important role PAN plays in $\mathrm{O}_{3}$ formation resulting from its ability to redistribute $\mathrm{NO}_{\mathrm{x}}$. Measurements of $\mathrm{CO}$ at $\mathrm{MBO}$ and meteorological indices show that long-range transport of $\mathrm{CO}$ from the heavily industrialized region of East Asia was significantly lower in 2006 compared to 2005 (Reidmiller et al., 2008). In the Western US both ground site data and MOPITT and TES satellite observations reveal a significant decrease (from $2-21 \%$ ) in springtime maximum $\mathrm{CO}$ between 2005 and 2006. They attribute this decrease to moderate biomass burning in Southeast Asia during 2006 and a transport pattern that limited the inflow of Asian pollution to the lower free troposphere over western North America.

Analysis of aircraft sulfate measurements from the DC8 over the central Pacific, C-130 over the east Pacific, and the Cessna over British Columbia indicated that most Asian aerosol over the ocean was in the lower free troposphere (2$5 \mathrm{~km}$ ). Large amounts of sulfate and little organic carbon were found in imported Asian pollution over Western Canada (Fig. 3). Asian plumes were not only significantly reduced of fine particle organic material, but organic compounds were attached to coarse particles in significant quantities. Scavenging of organic aerosol precursors by dust near source regions is suggested, and any formation of secondary organic aerosol during transport from Asian source regions across the Pacific was principally associated with the coarse particles (Leaitch et al., 2008; McKendry et al., 2008). In agreement with Zhang et al. (2008), an average of profiles indicated that trans-Pacific transport between 2 and $5 \mathrm{~km}$ during this period increased ozone by about $10 \mathrm{ppb}$ and fine particle sulfate by $0.2-0.5 \mu \mathrm{g} \mathrm{m}^{-3}$. Campaign-average simulations showed that anthropogenic East Asian sulfur emissions increased mean springtime sulfate in Western Canada at the surface by 25 $30 \%$ and accounted for $40 \%$ of the overall regional sulfate burden between 1 and $5 \mathrm{~km}$ (van Donkelaar et al., 2008). McNaughton et al. (2009) analyze data from the eastern Pacific and deduce that the presence of $\mathrm{CaCO}_{3}$ in Asian dust enhanced heterogeneous conversion of gas phase $\mathrm{S}$ and $\mathrm{N}$ into aerosol phase.

Fine particle median sulfate and water-soluble organic carbon (WSOC) concentrations in transported Asian air masses $(2-5 \mathrm{~km})$ were two to four times lower than North American air masses. In contrast, in air masses below $2 \mathrm{~km}$ median WSOC-sulfate ratios were consistently between one and two (Peltier et al., 2008). Sun et al. (2008) use measured aerosol mass spectra at Whistler peak to conclude that sulfate and $\mathrm{OA}$ were mostly present in external mixtures, indicating different origins, and OA was highly oxygenated, with an average organic-mass-to-organic-carbon ratio of 2.0 and an atomic ratio of oxygen-to-carbon of 0.8 . The nominal formula for $\mathrm{OA}$ was $\mathrm{C}_{1} \mathrm{H}_{1.52} \mathrm{~N}_{0.03} \mathrm{O}_{0.82}$ for the entire study. Heald et al. (2008) synthesize measurements of organic carbon compounds in both the gas and particle phases made upwind, over, and downwind of North America. The daytime mean total organic carbon ranges from 4 to $456 \mu \mathrm{gC} \mathrm{m}{ }^{-3}$ with organic aerosol making up $3-17 \%$ of this mean. Anthropogenic emissions account for much of this variability but correlation with tracers such as isoprene suggest that biogenic emissions are an important contributor. Dunlea et al. (2008) describe two case studies for pollution layers transported across the Pacific from the Asian continent, intercepted 3-4 days and 7-10 days downwind of Asia, respectively. These observations of sulfate and organic aerosol in aged Asian pollution layers are consistent with fast formation near the Asian continent, followed by washout during lofting and subsequent transformation during transport across the Pacific. No evidence is found to support significant secondary organic aerosol formation in the free troposphere.

A number of specialized measurements, new to the DC8 , were performed to define Pacific composition for the first time. Kim et al. (2008) provide specific gas phase $\mathrm{HCl}$ measurements from the marine boundary layer (MBL) to the lower stratosphere. They find that $\mathrm{HCl}$ mixing ratios are lower than previously believed and show evidence for its production in the mid troposphere by the de-chlorination of dust 

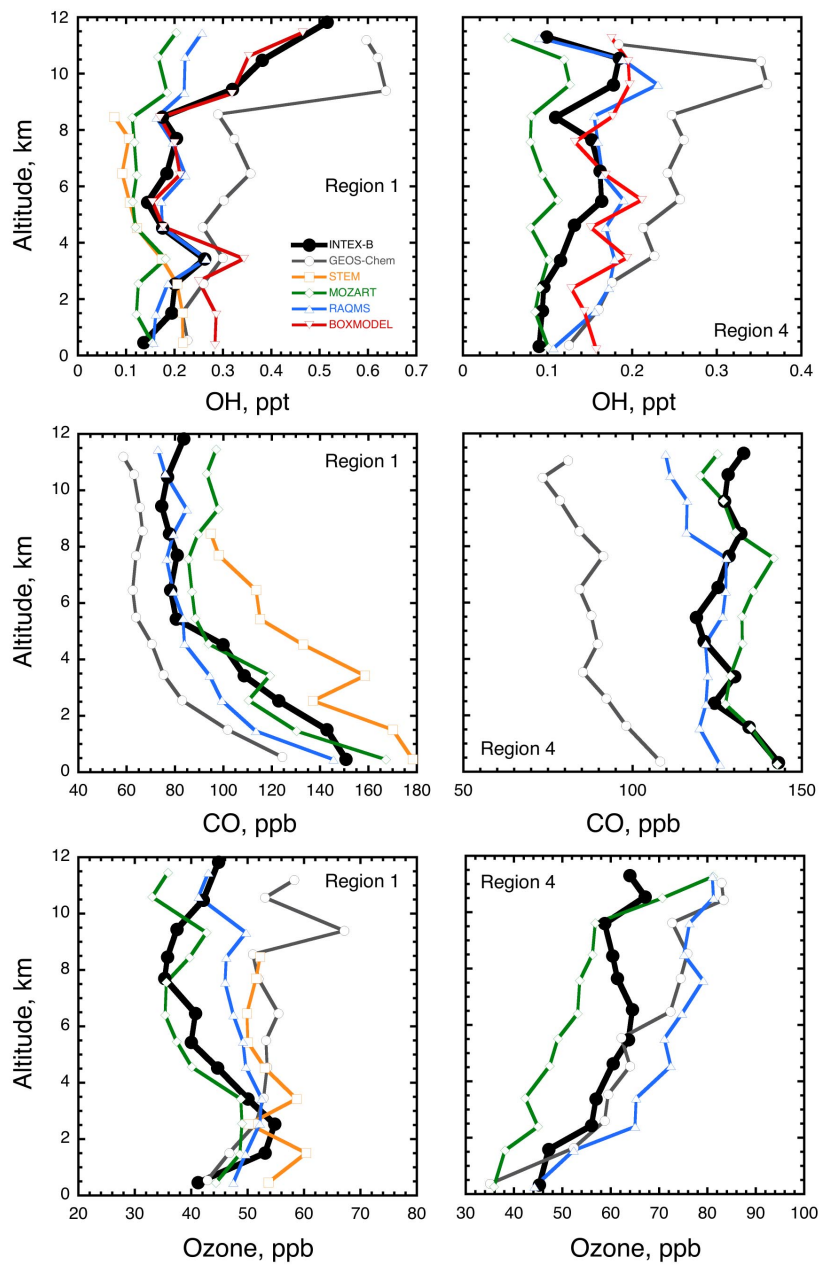

Fig. 4a. A comparison of INTEX-B observations over the Gulf of Mexico (Region 1) and subtropical Pacific (Region 4) with along track post mission simulations of select species. Regions 1 and 4 are as shown in Fig. 2a. STEM simulations were not available for Region 4.

aerosols. Over the Pacific, mercury was weakly correlated with anthropogenic tracers (Swartzendruber et al., 2008). A prominent feature of the INTEX-B dataset was frequent total depletion of $\mathrm{Hg}^{\circ}$ in the upper troposphere when stratospherically influenced air was encountered (Radke et al., 2007; Talbot et al., 2007; 2008). Global 3-D chemical transport models have been used to interpret new INTEX-B observations of methanol to further constrain the atmospheric methanol budget (Millet et al., 2008).

INTEX-B provided a most detailed exploration of $\mathrm{HO}_{\mathrm{x}}$ free radicals and its precursors. Simulation studies highlight many uncertainties in our quantitative understanding of the $\mathrm{HO}_{\mathrm{x}}-\mathrm{NO}_{\mathrm{x}}-\mathrm{O}_{3}$ system. Mao et al. (2009) deployed a new airborne $\mathrm{OH}$ reactivity instrument for the first time on the NASA DC-8 during the INTEX-B campaign. From the median vertical profile obtained over the Pacific, the measured $\mathrm{OH}$ reactivity was $30 \%$ higher than the $\mathrm{OH}$ reactivity from
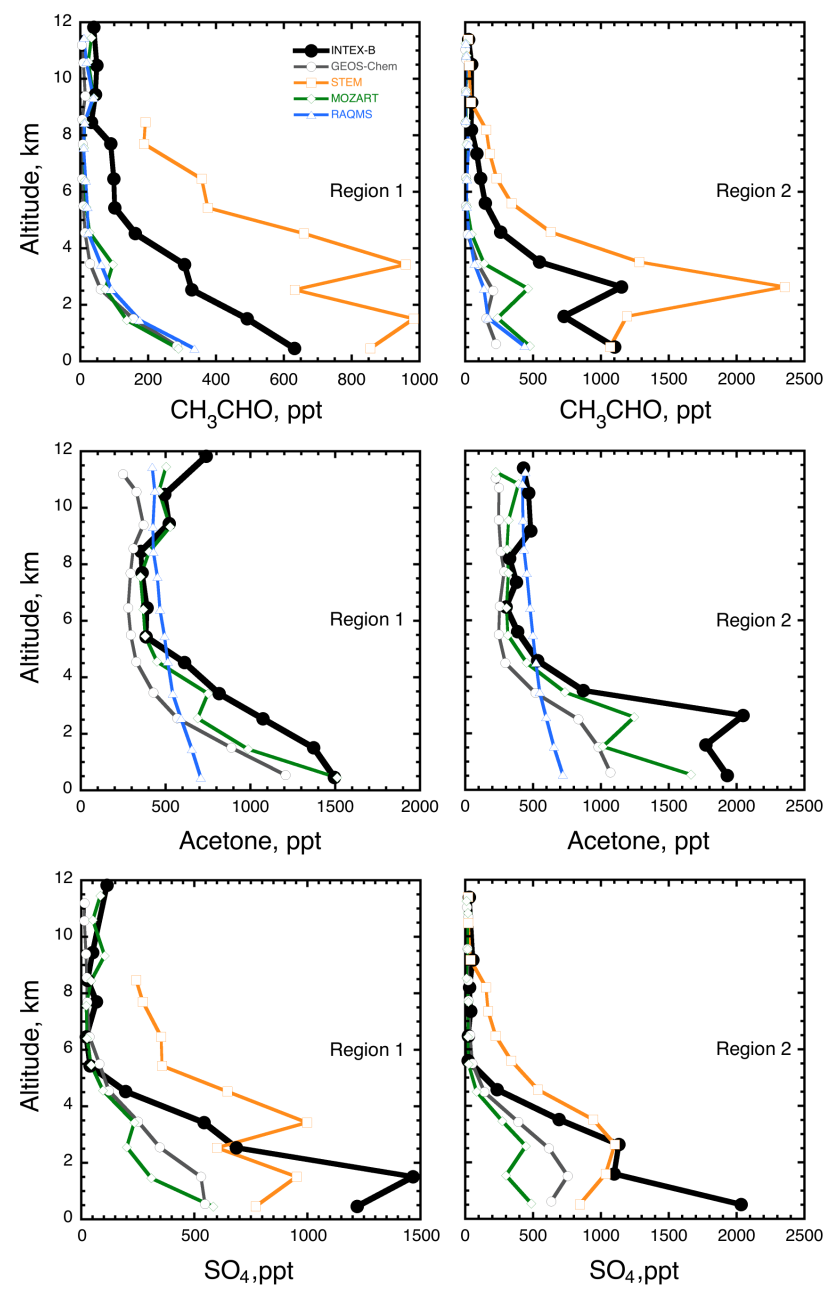

Fig. 4b. A comparison of INTEX-B observations over the Gulf of Mexico (Region 1) and Continental Mexico (Region 2) with along track post mission simulations of select species. Regions 1 and 2 are as shown in Fig. 2a.

steady state assumptions and some $200 \%$ higher than the $\mathrm{OH}$ reactivity calculated from the total measurements of all $\mathrm{OH}$ reactants. They attribute the missing $\mathrm{OH}$ reactivity to some highly reactive unmeasured VOCs that have $\mathrm{HCHO}$ as an oxidation product.

\subsection{Model simulations and INTEX-B observations}

INTEX-B provided a vast amount of observational data to both test CTMs and use them for further analysis. In general, the models in Table 4 captured the presence of pollution plumes and were an excellent aid in flight planning. However, significant quantitative differences remain. Figure 4a shows a comparison of selected observed constituents $\left(\mathrm{OH}, \mathrm{CO}\right.$, and $\left.\mathrm{O}_{3}\right)$ and results from post mission simulations over the Gulf of Mexico (Region 1) and Pacific (Region 4). As was previously observed in INTEX-A (Singh et al., 2007), model disagreements far exceed any potential error 

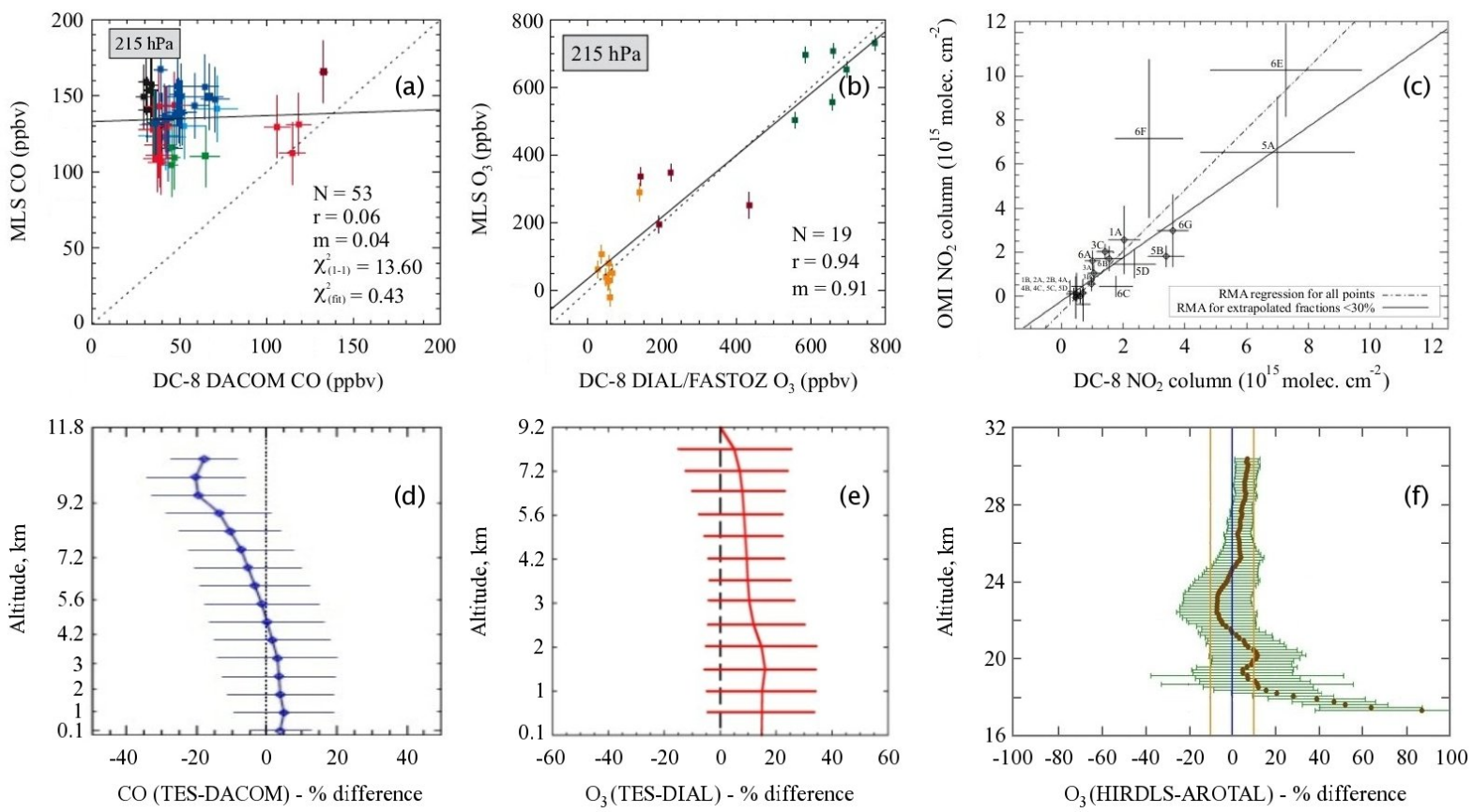

Fig. 5. Comparison of Aura satellite retrieved observations with DC-8 INTEX-B measurements. Adapted from Livesy et al. (2007), Boersma et al. (2008), Luo et al. (2007) and Nardi et al. (2008). See text for more details.

in observations and are also not consistent between missions (INTEX-A and INTEX-B). In case of GEOS-Chem, overestimation of $\mathrm{OH}$ appears to be a feature that is propagated throughout the INTEX-B Gulf and Pacific domain, and is principally responsible for $\mathrm{CO}$ underestimation. The "box model", which is most constrained by observations, is consistent with measurements above $\sim 4 \mathrm{~km}$ but significantly over predicts $\mathrm{OH}$ in the lower troposphere. Disagreements with observations are often much larger for more complex organic molecules such as acetaldehyde (Fig. 4b). Comparisons with CTMs of data from the entire campaign reveal an underprediction of organic aerosol mass in the MOZART model, but much smaller discrepancies with the GEOS-Chem model than found in previous studies over the western Pacific (Dunlea et al., 2008). Model disagreements can be due to a large number of factors that include emissions, boundary conditions, chemistry, meteorology, and even computational errors that need to be fully investigated. Plans are presently underway to create a community model inter-comparison and test project within the IGAC umbrella.

\subsection{Satellite derived results and analysis}

\subsubsection{Validation results}

Providing coincident observations for satellite validation of Aura instruments was a central theme for the DC- 8 in both phases of INTEX-B. A limited number of validation comparisons are summarized in Fig. 5 and more details referenced. Figure 5a, b shows a correlation plot of MLS re- trieved $\mathrm{CO}$ and $\mathrm{O}_{3}$ in the UT $(215 \mathrm{hPa})$ with the DC- 8 data indicating large differences in $\mathrm{CO}$ and relatively good agreement with $\mathrm{O}_{3}$ (Livesey et al., 2008). Figure 5c compares tropospheric $\mathrm{NO}_{2}$ column measurements from OMI with airborne observations over the Southern United States, Mexico, and the Gulf of Mexico during the INTEX-B campaign. Reasonably good correlation with no significant bias $\left(R^{2}=0.67\right.$, slope $\left.=0.99\right)$ is found for the ensemble of comparisons when the aircraft could spiral sufficiently low to sample most of the $\mathrm{NO}_{2}$ column (Boersma et al., 2008; Bucsela et al., 2008). TES CO data show good $( \pm 20 \%)$ overall agreement in the troposphere with the DC-8 in situ measurements (Fig. 5d) with some biases in the UT and LT (Luo et al., 2007). Comparisons of the TES $\mathrm{O}_{3}$ with the DC-8 DIAL (Fig. 5e) and ozonesonde data show a somewhat positive bias for TES (Richards et al., 2008; Nassar et al., 2008). Santee et al. (2007) provide an in depth comparison of limb derived MLS $\mathrm{HNO}_{3}$ data with that of INTEX-B and other observations.

Although INTEX-B primarily focused on the troposphere, one of the DC-8 remote sensing instruments (AROTAL) was targeted for stratospheric observations. Figure $5 \mathrm{f}$ shows a comparison of the DC-8 AROTAL and HIRDLS retrieved $\mathrm{O}_{3}$ with good agreement above $20 \mathrm{~km}$ and poor agreement in the lower stratosphere. Nardi et al. (2008) provide details on these comparisons and the reasons for the disagreements. Froidevaux et al. (2008) investigate $\mathrm{MLS} \mathrm{O}_{3}$ retrievals in the stratosphere and compare them with the INTEX-B AROTAL data. 
Table 8. Upper tropospheric $(7-12 \mathrm{~km})$ mixing ratios and tropospheric columns (surface-12 km) of key atmospheric constituents that are potentially amenable to space-based observation*

\begin{tabular}{|c|c|c|c|c|c|c|c|c|c|c|c|}
\hline Region* & & $\begin{array}{l}\mathrm{H}_{2} \mathrm{O} \\
(\mathrm{ppm})\end{array}$ & $\begin{array}{c}\mathrm{CO}_{2} \\
(\mathrm{ppm})\end{array}$ & $\begin{array}{c}\mathrm{O}_{3} \\
(\mathrm{ppb})\end{array}$ & $\begin{array}{c}\mathrm{CO} \\
(\mathrm{ppb})\end{array}$ & $\begin{array}{l}\mathrm{CH}_{4} \\
(\mathrm{ppb})\end{array}$ & $\begin{array}{l}\mathrm{N}_{2} \mathrm{O} \\
(\mathrm{ppb})\end{array}$ & $\begin{array}{l}\text { OCS } \\
(\mathrm{ppt})\end{array}$ & $\begin{array}{l}\mathrm{NO}_{2} \\
\text { (ppt) }\end{array}$ & $\begin{array}{c}\mathrm{HNO}_{3} \\
\text { (ppt) }\end{array}$ & $\begin{array}{l}\text { PAN } \\
\text { (ppt) }\end{array}$ \\
\hline \multirow[t]{2}{*}{1} & $\begin{array}{l}\text { UT } \\
\text { Trop. }\end{array}$ & $617 \pm 478^{* *}$ & $382 \pm 4.9$ & $38 \pm 10$ & $79.1 \pm 11.6$ & $1770 \pm 10$ & $321 \pm 0.3$ & $478 \pm 13$ & $2 \pm 49$ & $66 \pm 64$ & $50 \pm 148$ \\
\hline & $\begin{array}{l}\text { Column } \\
\text { (molec. } \mathrm{cm}^{-2} \text { ) }\end{array}$ & $\begin{array}{l}1.00 \mathrm{E}+23 \pm \\
3.48 \mathrm{E}+22\end{array}$ & $\begin{array}{c}6.55 \mathrm{E}+21 \pm \\
1.80 \mathrm{E}+20\end{array}$ & $\begin{array}{l}7.49 \mathrm{E}+17 \pm \\
8.57 \mathrm{E}+16\end{array}$ & $\begin{array}{l}1.84 \mathrm{E}+18 \pm \\
2.04 \mathrm{E}+17\end{array}$ & $\begin{array}{c}3.07 \mathrm{E}+19 \pm \\
9.27 \mathrm{E}+17\end{array}$ & $\begin{array}{l}5.02 \mathrm{E}+18 \pm \\
1.28 \mathrm{E}+17^{*}\end{array}$ & $\begin{array}{c}8.27 \mathrm{E}+15 \pm \\
2.74 \mathrm{E}+14\end{array}$ & $\begin{array}{l}1.78 \mathrm{E}+15 \pm \\
2.13 \mathrm{E}+15\end{array}$ & $\begin{array}{c}4.96 \mathrm{E}+15 \pm \\
1.64 \mathrm{E}+15\end{array}$ & $\begin{array}{c}2.09 \mathrm{E}+15 \pm \\
1.79 \mathrm{E}+15\end{array}$ \\
\hline \multirow[t]{2}{*}{2} & $\begin{array}{l}\text { UT } \\
\text { Trop. }\end{array}$ & $368 \pm 328$ & $382 \pm 5.1$ & $39 \pm 8$ & $75.3 \pm 7.8$ & $1770 \pm 8$ & $321 \pm 0.1$ & $472 \pm 8$ & $39 \pm 47$ & $59 \pm 80$ & $23 \pm 25$ \\
\hline & $\begin{array}{l}\text { Column } \\
\text { (molec. } \mathrm{cm}^{-2} \text { ) }\end{array}$ & $\begin{array}{c}3.04 \mathrm{E}+22 \pm \\
1.22 \mathrm{E}+22\end{array}$ & $\begin{array}{c}4.83 \mathrm{E}+21 \pm \\
1.20 \mathrm{E}+20\end{array}$ & $\begin{array}{c}5.62 \mathrm{E}+17 \pm \\
7.61 \mathrm{E}+16\end{array}$ & $\begin{array}{l}1.32 \mathrm{E}+18 \pm \\
5.46 \mathrm{E}+17\end{array}$ & $\begin{array}{c}2.25 \mathrm{E}+19 \pm \\
6.35 \mathrm{E}+17\end{array}$ & $\begin{array}{l}3.53 \mathrm{E}+18 \pm \\
8.92 \mathrm{E}+16^{*}\end{array}$ & $\begin{array}{c}6.02 \mathrm{E}+15 \pm \\
1.65 \mathrm{E}+14\end{array}$ & $\begin{array}{c}4.91 \mathrm{E}+15 \pm \\
1.60 \mathrm{E}+16\end{array}$ & $\begin{array}{c}4.60 \mathrm{E}+15 \pm \\
4.28 \mathrm{E}+15\end{array}$ & $\begin{array}{c}3.91 \mathrm{E}+15 \pm \\
5.33 \mathrm{E}+15\end{array}$ \\
\hline \multirow[t]{2}{*}{3} & $\begin{array}{l}\text { UT } \\
\text { Trop. }\end{array}$ & $315 \pm 300$ & $385 \pm 8.4$ & $74 \pm 14$ & $134 \pm 30$ & $1820 \pm 14$ & $320 \pm 0.6$ & $493 \pm 29$ & $20 \pm 27$ & $70 \pm 70$ & $166 \pm 143$ \\
\hline & $\begin{array}{l}\text { Column } \\
\text { (molec. } \mathrm{cm}^{-2} \text { ) }\end{array}$ & $\begin{array}{c}4.66 \mathrm{E}+22 \pm \\
1.47 \mathrm{E}+22\end{array}$ & $\begin{array}{c}6.92 \mathrm{E}+21 \pm \\
1.95 \mathrm{E}+209.13 \mathrm{E}+16\end{array}$ & $\begin{array}{c}1.15 \mathrm{E}+18 \pm \\
1.71 \mathrm{E}+17\end{array}$ & $\begin{array}{c}2.62 \mathrm{E}+18 \pm \\
9.47 \mathrm{E}+17\end{array}$ & $\begin{array}{c}3.28 \mathrm{E}+19 \pm \\
1.58 \mathrm{E}+17\end{array}$ & $\begin{array}{c}5.74 \mathrm{E}+18 \pm \\
2.82 \mathrm{E}+14\end{array}$ & $\begin{array}{l}8.73+15 \pm \\
2.64 \mathrm{E}+15\end{array}$ & $\begin{array}{l}9.13 \mathrm{E}+14 \pm \\
5.49 \mathrm{E}+14\end{array}$ & $\begin{array}{l}1.39 \mathrm{E}+15 \\
1.64 \mathrm{E}+15\end{array}$ & $3.26 \mathrm{E}+15 \pm$ \\
\hline \multirow[t]{2}{*}{4} & $\begin{array}{l}\text { UT } \\
\text { Trop. }\end{array}$ & $208 \pm 258$ & $385 \pm 7.3$ & $64 \pm 13$ & $130 \pm 19$ & $1810 \pm 11$ & $3.20 \pm 0.5$ & $483 \pm 16$ & $33 \pm 30$ & $32 \pm 20$ & $168 \pm 165$ \\
\hline & $\begin{array}{l}\text { Column } \\
\text { (molec. } \mathrm{cm}^{-2} \text { ) }\end{array}$ & $\begin{array}{c}8.52 \mathrm{E}+22 \pm \\
2.58 \mathrm{E}+22\end{array}$ & $\begin{array}{c}6.81 \mathrm{E}+21 \pm \\
1.78 \mathrm{E}+20\end{array}$ & $\begin{array}{c}1.00 \mathrm{E}+18 \pm \\
9.55 \mathrm{E}+16\end{array}$ & $\begin{array}{c}2.30 \mathrm{E}+18 \pm \\
1.62 \mathrm{E}+17\end{array}$ & $\begin{array}{c}3.21 \mathrm{E}+19 \pm \\
8.83 \mathrm{E}+17\end{array}$ & $\begin{array}{l}3.48 \mathrm{E}+18 \pm \\
7.08 \mathrm{E}+16^{*}\end{array}$ & $\begin{array}{c}8.60 \mathrm{E}+15 \pm \\
2.68 \mathrm{E}+14\end{array}$ & $\begin{array}{l}1.04 \mathrm{E}+15 \pm \\
1.93 \mathrm{E}+15\end{array}$ & $\begin{array}{c}1.62 \mathrm{E}+15 \pm \\
4.42 \mathrm{E}+14\end{array}$ & $\begin{array}{c}1.88 \mathrm{E}+15 \pm \\
8.91 \mathrm{E}+14\end{array}$ \\
\hline Region & & $\begin{array}{l}\mathrm{CH}_{2} \mathrm{O} \\
(\mathrm{ppt})\end{array}$ & $\begin{array}{l}\text { Acetone } \\
(\mathrm{ppt})\end{array}$ & $\underset{(\mathrm{ppt})}{\mathrm{CH}_{3} \mathrm{OH}}$ & $\underset{(\mathrm{ppt})}{\mathrm{CH}_{3} \mathrm{OOH}}$ & $\begin{array}{r}\mathrm{H}_{2} \mathrm{O}_{2} \\
\text { (ppt) }\end{array}$ & $\begin{array}{l}\mathrm{HCN} \\
(\mathrm{ppt})\end{array}$ & $\begin{array}{l}\mathrm{CH}_{3} \mathrm{CN} \\
(\mathrm{ppt})\end{array}$ & $\begin{array}{l}\mathrm{CH}_{3} \mathrm{Cl} \\
(\mathrm{ppt})\end{array}$ & $\begin{array}{l}\mathrm{C}_{2} \mathrm{H}_{6} \\
\text { (ppt) }\end{array}$ & $\begin{array}{l}\mathrm{C}_{2} \mathrm{H}_{2} \\
\text { (ppt) }\end{array}$ \\
\hline \multirow[t]{2}{*}{1} & $\begin{array}{l}\text { UT } \\
\text { Trop. }\end{array}$ & $47 \pm 70$ & $460 \pm 275$ & $470 \pm 405$ & $361 \pm 173$ & $480 \pm 360$ & $228 \pm 75$ & $120 \pm 29$ & $569 \pm 18$ & $459 \pm 102$ & $73 \pm 529$ \\
\hline & $\begin{array}{l}\text { Column } \\
\text { (molec. } \mathrm{cm}^{-2} \text { ) }\end{array}$ & $\begin{array}{c}9.54 \mathrm{E}+15 \pm \\
4.72 \mathrm{E}+15\end{array}$ & $\begin{array}{c}1.42 \mathrm{E}+16 \pm \\
3.47 \mathrm{E}+15\end{array}$ & $\begin{array}{l}1.74 \mathrm{E}+16 \pm \\
6.50 \mathrm{E}+15\end{array}$ & $\begin{array}{c}8.13 E+15 \pm \\
1.63 E+15\end{array}$ & $\begin{array}{c}2.00 \mathrm{E}+16 \pm \\
6.15 \mathrm{E}+15\end{array}$ & $\begin{array}{c}5.49 \mathrm{E}+15 \pm \\
1.13 \mathrm{E}+15\end{array}$ & $\begin{array}{c}2.22 \mathrm{E}+15 \pm \\
2.40 \mathrm{E}+14\end{array}$ & $\begin{array}{c}1.05 \mathrm{E}+16 \pm \\
1.05 \mathrm{E}+16 \pm 7.20 \mathrm{E}+14\end{array}$ & $\begin{array}{c}1.40 \mathrm{E}+16 \pm \\
4.94 \mathrm{E}+15\end{array}$ & $\begin{array}{c}3.25 \mathrm{E}+15 \pm \\
1.01 \mathrm{E}+15\end{array}$ \\
\hline \multirow[t]{2}{*}{2} & $\begin{array}{l}\text { UT } \\
\text { Trop. }\end{array}$ & $33 \pm 56$ & $401 \pm 126$ & $437 \pm 220$ & $285 \pm 83.3$ & $373 \pm 216$ & $191 \pm 55$ & $129 \pm 44$ & $556 \pm 9$ & $406 \pm 68.6$ & $54 \pm 19$ \\
\hline & $\begin{array}{l}\text { Column } \\
\text { (molec. } \mathrm{cm}^{-2} \text { ) }\end{array}$ & $\begin{array}{c}1.69 \mathrm{E}+16 \pm \\
9.41 \mathrm{E}+15\end{array}$ & $\begin{array}{c}8.98 \mathrm{E}+15 \pm \\
4.66 \mathrm{E}+15\end{array}$ & $\begin{array}{l}1.18 \mathrm{E}+16 \pm \\
8.60 \mathrm{E}+15\end{array}$ & $\begin{array}{c}4.36 \mathrm{E}+15 \pm \\
6.60 \mathrm{E}+14\end{array}$ & $\begin{array}{c}1.06 \mathrm{E}+16 \pm \\
2.64 \mathrm{E}+15\end{array}$ & $\begin{array}{c}5.96 \mathrm{E}+15 \pm \\
3.90 \mathrm{E}+15\end{array}$ & $\begin{array}{c}1.75 \mathrm{E}+15 \pm \\
3.46 \mathrm{E}+14\end{array}$ & $\begin{array}{c}7.25 \mathrm{E}+15 \pm \\
2.56 \mathrm{E}+14\end{array}$ & $\begin{array}{l}7.16 \mathrm{E}+15 \\
2.29 \mathrm{E}+15\end{array}$ & $\begin{array}{c}3.58 \mathrm{E}+15 \pm \\
5.40 \mathrm{E}+15\end{array}$ \\
\hline \multirow[t]{2}{*}{3} & $\begin{array}{l}\text { UT } \\
\text { Trop. }\end{array}$ & $37 \pm 51$ & $891 \pm 340$ & $1540 \pm 1040$ & $570 \pm 281$ & $483 \pm 276$ & $268 \pm 84$ & $137 \pm 29$ & $564 \pm 29$ & $1030 \pm 237$ & $227 \pm 106$ \\
\hline & $\begin{array}{l}\text { Column } \\
6.63 \mathrm{E}+14 \\
\left(\text { molec. } \mathrm{cm}^{-2}\right)\end{array}$ & $\begin{array}{l}1.90 \mathrm{E}+15 \pm \\
2.45 \mathrm{E}+15\end{array}$ & $\begin{array}{c}1.35 \mathrm{E}+16 \pm \\
5.70 \mathrm{E}+15\end{array}$ & $\begin{array}{c}2.21 \mathrm{E}+16 \pm \\
1.98 \mathrm{E}+15\end{array}$ & $\begin{array}{c}9.73 \mathrm{E}+15 \pm \\
4.25 \mathrm{E}+15\end{array}$ & $\begin{array}{c}1.11 \mathrm{E}+16 \pm \\
7.79 \mathrm{E}+14\end{array}$ & $\begin{array}{c}5.02 \mathrm{E}+15 \pm \\
3.16 \mathrm{E}+14\end{array}$ & $\begin{array}{c}2.11 \mathrm{E}+15 \pm \\
2.76 \mathrm{E}+14\end{array}$ & $\begin{array}{c}9.74 \mathrm{E}+15 \pm \\
1.73 \mathrm{E}+15\end{array}$ & $\begin{array}{c}2.34 \mathrm{E}+16 \pm \\
6.42 \mathrm{E}+14\end{array}$ & $4.70 \mathrm{E}+15 \pm$ \\
\hline \multirow[t]{2}{*}{4} & $\begin{array}{l}\text { UT } \\
\text { Trop. }\end{array}$ & $47 \pm 47$ & $662 \pm 219$ & $947 \pm 543$ & $592 \pm 251$ & $405 \pm 319$ & $252 \pm 94$ & $162 \pm 55$ & $585 \pm 19$ & $801 \pm 148$ & $210 \pm 76$ \\
\hline & $\begin{array}{l}\text { Column } \\
\text { (molec. } \mathrm{cm}^{-2} \text { ) }\end{array}$ & $\begin{array}{c}3.65 \mathrm{E}+15 \pm \\
8.70 \mathrm{E}+14\end{array}$ & $\begin{array}{c}1.02 \mathrm{E}+16 \pm \\
1.87 \mathrm{E}+15\end{array}$ & $\begin{array}{c}1.31 \mathrm{E}+16 \pm \\
4.16 \mathrm{E}+15\end{array}$ & $\begin{array}{l}1.28 \mathrm{E}+16 \pm \\
2.44 \mathrm{E}+15\end{array}$ & $\begin{array}{c}1.79 \mathrm{E}+16 \pm \\
4.53 \mathrm{E}+15\end{array}$ & $\begin{array}{c}5.58 \mathrm{E}+15 \pm \\
1.01 \mathrm{E}+15\end{array}$ & $\begin{array}{c}2.38 \mathrm{E}+15 \pm \\
3.64 \mathrm{E}+14\end{array}$ & $\begin{array}{c}9.99 \mathrm{E}+15 \pm \\
2.91 \mathrm{E}+14\end{array}$ & $\begin{array}{l}1.77 \mathrm{E}+16 \pm \\
2.14 \mathrm{E}+15\end{array}$ & $\begin{array}{c}3.43 \mathrm{E}+15 \pm \\
6.52 \mathrm{E}+14\end{array}$ \\
\hline
\end{tabular}

* Regions are as defined in Fig. 2a. Terrain effects in Region 2 cause the column to be $2-12 \mathrm{~km}$ above surface. Missing data in column calculation were interpolated.

** Mean \pm one sigma.

Extensive validation of $\mathrm{CO}$ from AIRS and MOPITT was also carried out. Emmons et al. (2008) use INTEXB/MILAGRO and other in situ observations to conclude that a significant positive bias, around $20 \%$, is present in MOPITT derived CO. Comparisons to the long-term records revealed that this bias is increasing with time. Possible causes for this drift and improvements in future retrievals have been suggested. Felker et al. (2008) blend GOES water vapor and TES ozone to derive a Multi-sensor UT Ozone Product (MUTOP) that has the advantage of producing the spatial coverage of a geostationary image while retaining TES's ability to resolve UT ozone. Results show 70-80\% of TESobserved UT ozone variability can be explained by correlation with these two dynamical tracers. It is noted that satellite retrievals are continually being refined and it is possible that the comparisons shown here will improve over time.

\subsubsection{Satellite based analysis}

OMI NO 2 satellite observations were used to constrain Asian anthropogenic $\mathrm{NO}_{\mathrm{x}}$ emissions, indicating a factor of two increases in emissions from China from 2000 to 2006 (Zhang et al., 2008). Halland et al. (2008) quantify the vertical transport of $\mathrm{CO}$ by deep mesoscale convective systems and assess the ability of TES to detect the resulting enhanced $\mathrm{CO}$ in the upper atmosphere. A squall line similar to one in INTEX-B was simulated using the Goddard Cumulus Ensemble model. Results show that the simulated squall line transports the greatest mass of CO in the UT. They conclude that TES has sufficient sensitivity to resolve convectively lofted $\mathrm{CO}$, as long as the retrieval scene is cloud-free. Arellano et al. (2007) present a global chemical data assimilation system and apply it to constrain global tropospheric $\mathrm{CO}$ by assimilating meteorological observations of temperature and horizontal wind velocity and satellite CO retrieved from MOPITT. 
They conclude that MOPITT data assimilation provides significant improvements in capturing the observed $\mathrm{CO}$ variability. Shim et al. (2009) use concurrent tropospheric $\mathrm{O}_{3}$ and CO vertical profiles from TES over Mexico City to characterize mega-city pollution outflow on a regional scale. They find that TES captures much of the spatial and day-to-day variability seen in the in situ data for $\mathrm{O}_{3}$, but not for $\mathrm{CO}$ and cautions against using such correlations. Y. Shinozuka and co-workers (private communication, 2008) report that number concentration of particles $>100 \mathrm{~nm}$ are a proxy for $\mathrm{CCN}$ and can be stratified by two optical properties, the extinction coefficient and its wavelength dependence. They use data from INTEX-B/MILAGRO and INTEX-A to quantify these relationships and explore the feasibility of satellite retrieval of CCN concentration from optical property measurements.

It is increasingly possible to retrieve many organic and inorganic species from existing satellite obtained spectra (e.g. acetone, methanol, $\mathrm{HCHO}, \mathrm{PAN}, \mathrm{CO}_{2}, \mathrm{CH}_{4}$ ) (Beer et al., 2001; Frankenberg et al., 2005; Glatthor et al., 2007; Rinsland et al., 2007). In Table 8, we provide UT mixing ratios and tropospheric columns of key atmospheric constituents that are potentially retrievable from existing satellite data for the four selected regions of INTEX-B (Fig. 2a). The variability in the $\mathrm{CO}_{2}$ column and UT mixing ratios is $2.7 \%$ $(\approx 10 \mathrm{ppm})$ and $1.5 \%(\approx 6 \mathrm{ppm})$, respectively, irrespective of the nature of underlying sources. Filtering the data for only clean conditions (bottom two CO quartiles) had little effect $(<5 \%)$ on the relative variability. Boundary layer $(1-2 \mathrm{~km})$ $\mathrm{CO}_{2}$ elevation due to urban pollution and reductions due to biosphere uptake would need to be $40 \mathrm{ppm}$ or more to be detected in the $\mathrm{CO}_{2}$ column. Airborne observations indicate that these elevations are typically less than $15 \mathrm{ppm}$ and only on rare occasions may exceed $40 \mathrm{ppm}$ (Choi et al., 2008). Relating satellite derived atmospheric columns of $\mathrm{CO}_{2}(\mathrm{Or}-$ biting Carbon Observatory; http://oco.jpl.nasa.gov/; Miller et al., 2007) to its surface sources and sinks would be extremely challenging.

\section{Conclusions}

The INTEX-B/MILAGRO measurements provide a rich data set for describing the composition and chemistry of the troposphere over Mexico, the Gulf of Mexico, the Pacific, and western North America, for investigating the transformation of gases and aerosols during long-range transport, for the radiation balance of the troposphere, and for validating a variety of satellite observations as well as models of chemistry and transport. The results presented in this special issue of ACP represent only the initial analysis, and much more integrated analysis is expected in the near future. The data are available to all interested parties for further analysis.

\section{Appendix A}

\section{List of Acronyms}

\begin{tabular}{|c|c|}
\hline $\mathrm{ACP}$ & Atmospheric Chemistry and Physics \\
\hline AIRS & Atmospheric Infrared Sounder \\
\hline AOD & Aerosol Optical Depth \\
\hline AROTAL & $\begin{array}{l}\text { Airborne Raman Ozone Temperature and } \\
\text { Aerosol Lidar }\end{array}$ \\
\hline CIMS & Chemical Ionization Mass Spectrometry \\
\hline CTM & Chemical Transport Model \\
\hline DLR & $\begin{array}{l}\text { Deutschen Zentrum für Luft- und } \\
\text { Raumfahrt }\end{array}$ \\
\hline DU & $\begin{array}{l}\text { Dobson Unit }\left(2.7 \times 10^{16} \text { ozone molecules }\right. \\
\left.\text { per } \mathrm{cm}^{2}\right)\end{array}$ \\
\hline GOES & $\begin{array}{l}\text { Geostationary Operational Environmental } \\
\text { Satellite }\end{array}$ \\
\hline HIRDLS & High Resolution Dynamic Limb Sounder \\
\hline ICARTT & $\begin{array}{l}\text { International Consortium for Atmospheric } \\
\text { Research on Transport and Transformation }\end{array}$ \\
\hline IGAC & $\begin{array}{l}\text { International Global Atmospheric } \\
\text { Chemistry }\end{array}$ \\
\hline INTEX-NA & $\begin{array}{l}\text { Intercontinental Chemical Transport } \\
\text { Experiment-North America }\end{array}$ \\
\hline IONS & INTEX Ozonesonde Network Study \\
\hline LIF & Laser Induced Fluorescence \\
\hline LIS & Lightning Imaging Sensor \\
\hline LRLN & Long-Range Lightning Network \\
\hline LS & Lower Stratosphere \\
\hline MBO & Mount Bachelor Observatory \\
\hline MILAGRO & $\begin{array}{l}\text { Megacity Initiative: Local Global and } \\
\text { Research Observations }\end{array}$ \\
\hline MISR & Multiangle Imaging SpectroRadiometer \\
\hline MLS & Microwave Limb Sounder \\
\hline MOPITT & $\begin{array}{l}\text { Measurement of Pollution in the } \\
\text { Troposphere }\end{array}$ \\
\hline MOZART & Model of Ozone and Related Tracers \\
\hline MODIS & $\begin{array}{l}\text { Moderate Resolution Imaging } \\
\text { Spectroradiometer }\end{array}$ \\
\hline NA & North America \\
\hline NASA & $\begin{array}{l}\text { National Aeronautics and Space } \\
\text { Administration }\end{array}$ \\
\hline NCEP & $\begin{array}{l}\text { National Centers for Environmental } \\
\text { Prediction }\end{array}$ \\
\hline NLDN & National Lightning Detection Network \\
\hline $\mathrm{OA}$ & Organic Aerosol \\
\hline $\mathrm{OC}$ & Organic Carbon \\
\hline OMI & Ozone Monitoring Instrument \\
\hline OVOC & Oxygenated Volatile Organic Chemicals \\
\hline PAN & Peroxy Acetyl Nitrates \\
\hline RAQMS & Real-time Air Quality Modeling System \\
\hline SCIAMACHY & $\begin{array}{l}\text { Scanning Imaging Absorption } \\
\text { Spectrometer } \\
\text { for Atmospheric Chartography }\end{array}$ \\
\hline SSFR & Solar Spectral Flux Radiometer \\
\hline STEM & Sulfur Transport and Deposition Model \\
\hline TES & Tropospheric Emission Spectrometer \\
\hline TOMS & Total Ozone Measuring Spectrometer \\
\hline UT & Upper Troposphere \\
\hline WSOC & Water Soluble Organic Carbon \\
\hline
\end{tabular}


Acknowledgements. We thank all INTEX-B/MILAGRO participants and sponsoring agencies for making this project possible. DC-8 and C-130 activities were supported by the NASA Tropospheric Chemistry and NSF Atmospheric Chemistry Programs. We very much appreciate the dedicated efforts of all personnel associated with INTEX-B activities from NASA Dryden, NASA Wallops and Univ. of North Dakota in making this campaign a success.

Edited by: U. Pöschl

\section{References}

A. F. Arellano Jr., , Raeder, K., Anderson, J. L., Hess, P. G., Emmons, L. K., Edwards, D. P., Pfister, G. G., Campos, T. L., and Sachse, G. W.: Evaluating model performance of an ensemblebased chemical data assimilation system during INTEX-B field mission, Atmos. Chem. Phys., 7, 5695-5710, 2007, http://www.atmos-chem-phys.net/7/5695/2007/.

Beer, R., Glavich, T. A., and Rider, D. M.: Tropospheric emission spectrometer for the Earth Observing System's Aura satellite, Appl. Optics, 40(15), 2356-2367, 2001.

Boersma, K. F., Jacob, D. J., Bucsela, E. J., et al.: Validation of OMI tropospheric $\mathrm{NO}_{2}$ observations during INTEX-B and application to constrain $\mathrm{NO}_{\mathrm{x}}$ emissions over the eastern United States and Mexico, Atmos. Environ., 42(19), 4480-4497, 2008.

Bucsela, E. J., Perring, A. E., Cohen, R. C., Boersma, K. F., Celarier, E. A., Gleason, J. F., Wenig, M. O., Bertram, T. H., Wooldridge, P. J., Dirksen, R., and Veefkind, J. P.: Comparison of tropospheric $\mathrm{NO}_{2}$ from in situ aircraft measurements with near-real-time and standard product data from OMI, J. Geophys. Res., 113, D16S31, doi:10.1029/2007JD008838, 2008.

Chan, K. C. and Yao, X.: Air pollution in mega cities in China, Atmos. Environ., 42(1), 1-42, 2008.

Choi, Y., Vay, S. A., Vadrevu, K. P., Soja, A. J., Woo, J.-H., Nolf, S. R., Sachse, G. W., Diskin, G. S., Blake, D. R., Blake, N. J., Singh, H. B., Avery, M. A., Fried, A., Pfister, L., and Fuelberg, H. E, : Characteristics of the atmospheric $\mathrm{CO}_{2}$ signal as observed over the conterminous United States during INTEX-NA, J. Geophys. Res., 113, D07301, doi:10.1029/2007JD008899, 2008.

Dunlea, E. J., DeCarlo, P. F., Aiken, A. C., Kimmel, J. R., Peltier, R. E., Weber, R. J., Tomlison, J., Collins, D. R., Shinozuka, Y., McNaughton, C. S., Howell, S. G., Clarke, A. D., Emmons, L. K., Apel, E. C., Pfister, G. G., van Donkelaar, A., Martin, R. V., Millet, D. B., Heald, C. L., and Jimenez, J. L.: Evolution of Asian aerosols during transpacific transport in INTEX-B, Atmos. Chem. Phys. Discuss., 8, 15375-15461, 2008, http://www.atmos-chem-phys-discuss.net/8/15375/2008/.

Emmons, L. K., Edwards, D. P., Deeter, M. N., Gille, J. C., Campos, T., Nedelec, P., Novelli, P., and Sachse, G.: Measurements of Pollution in the Troposphere (MOPITT) validation through 2006, Atmos. Chem. Phys. Discuss., 8, 18091-18109, 2008, http://www.atmos-chem-phys-discuss.net/8/18091/2008/.

EPA: Hemispheric transport of air pollutants, interim report of the Convention on Long-range Transboundary Air Pollution, 1-176, http://www.htop.org, 2007.

Fehsenfeld, F. C., Ancellet, G., Bates, T. S., Goldstein, A. H., Hardesty, R. M., Honrath, R., Law, K. S., Lewis, A. C., Leaitch, R.,
McKeen, S., Meagher, J., Parrish, D. D., Pszenny, A. A., Russell, P. B., Schlager, H., Seinfeld, J., Talbot, R. and Zbinden, R.: International Consortium for Atmospheric Research on Transport and Transformation (ICARTT): North America to Europe Overview of the 2004 summer field study, J. Geophys. Res., 111, D23S01, doi:10.1029/2006JD007829, 2006.

Felker, S. R., Moody, J. L., Wimmers, A. J., Osterman, G., Bowman, K., Thompson, A. M., and Tarasick, D. W.: A Multi-sensor Upper Tropospheric Ozone Product (MUTOP) based on TES ozone and GOES water vapor: II. Validation with ozonesondes, J. Geophys. Res., submitted, 2008.

Frankenberg, C., Meirink, J. F., van Weele, M., Platt, U., and Wagner, T.: Assessing methane emissions from global spaceborne observations, Science, 308, 1010-1014, 2005.

Froidevaux, L., Jiang, Y. B., Lambert, A., Livesey, N. J., et al.: Validation of Aura Microwave Limb Sounder stratospheric ozone measurements, J. Geophys. Res., 113, D15S20, doi:10.1029/2007JD008771, 2008.

Glatthor, N., von Clarmann, T., Fischer, H., Funke, B., Grabowski, U., Höpfner, M., Kellmann, S., Kiefer, M., Linden, A., Milz, M., Steck, T., and Stiller, G. P.: Global peroxyacetyl nitrate (PAN) retrieval in the upper troposphere from limb emission spectra of the Michelson Interferometer for Passive Atmospheric Sounding (MIPAS), Atmos. Chem. Phys. Discuss., 7, 13911420, 2007, http://www.atmos-chem-phys-discuss.net/7/1391/2007/.

Halland, J. J., Fuelberg, H. E., Pickering, K. E., and Luo, M.: Identifying convective transport of carbon monoxide by comparing remotely sensed observations from TES with cloud modeling simulations, Atmos. Chem. Phys. Discuss., 8, 19201-19247, 2008, http://www.atmos-chem-phys-discuss.net/8/19201/2008/.

Heald, C. L., Goldstein, A. H., Allan, J. D., Aiken, A. C., Apel, E., Atlas, E. L., Baker, A. K., Bates, T. S., Beyersdorf, A. J., Blake, D. R., Campos, T., Coe, H., Crounse, J. D., DeCarlo, P. F., de Gouw, J. A., Dunlea, E. J., Flocke, F. M., Fried, A., Goldan, P., Griffin, R. J., Herndon, S. C., Holloway, J. S., Holzinger, R., Jimenez, J. L., Junkermann, W., Kuster, W. C., Lewis, A. C., Meinardi, S., Millet, D. B., Onasch, T., Polidori, A., Quinn, P. K., Riemer, D. D., Roberts, J. M., Salcedo, D., Sive, B., Swanson, A. L., Talbot, R., Warneke, C., Weber, R. J., Weibring, P., Wennberg, P. O., Worsnop, D. R., Wittig, A. E., Zhang, R., Zheng, J., and Zheng, W.: Total observed organic carbon (TOOC) in the atmosphere: a synthesis of North American observations, Atmos. Chem. Phys., 8, 2007-2025, 2008, http://www.atmos-chem-phys.net/8/2007/2008/.

Hoell, J. M., Davis, D. D., Liu, S. C., Newell, R., Shipham, M., Akimoto, H., McNeal, R. J., Bendura, R. J., and Drewry, J. W.: Pacific Exploratory Mission-West A (PEM-West A): SeptemberOctober 1991, J. Geophys. Res., 101, 1641-1653, 1996.

Hoell, J. M., Davis, D. D., Liu, S. C., Newell, R. E., Akimoto, H., McNeal, R. J., and Bendura, R. J.: The Pacific Exploratory Mission-West Phase B: February-March 1994, J. Geophys. Res., 102, 28223-28239, 1997.

Holloway, T., Fiore, A. M., and Hastings, M. G.: Intercontinental Transport of Air Pollution: Will emerging science lead to a new hemispheric treaty?, Environ. Sci. Technol., 37, 4535-4542, 2003.

Hudman, R. C., Jacob, D. J., Turquety, S., et al.: Surface and lightning sources of nitrogen oxides over the United States: magni- 
tudes, chemical evolution, and outflow?, J. Geophys. Res., 112, D12S05, doi:10.1029/2006JD007912, 2007.

Jacob, D. J., Crawford, J. H., Kleb, M. M., Connors, V. S., Bendura, R. J., Raper, J. L., Sachse, G. W., Gille, J. C., Emmons, L., and Heald, C. L.: Transport and Chemical Evolution over the Pacific (TRACE-P) aircraft mission: Design, execution, and first results, J. Geophys. Res., 108(D20), 9000, doi:10.1029/2002JD003276, 2003.

Kim, S., Huey, L. G., Stickel, R. E., Pierce, R. B., Chen, G., Avery, M. A., Dibb, J. E., Diskin, G. S., Sachse, G. W., McNaughton, C. S., Clarke, A. D., Anderson, B. E., and Blake, D. R.: Airborne measurements of $\mathrm{HCl}$ from the marine boundary layer to the lower stratosphere over the North Pacific Ocean during INTEXB, Atmos. Chem. Phys. Discuss., 8, 3563-3595, 2008,

http://www.atmos-chem-phys-discuss.net/8/3563/2008/.

Leaitch, W. R., Macdonald, A. M., Anlauf, K. G., Liu, P. S. K., Toom-Sauntry, D., Li, S.-M., Liggio, J., Hayden, K., Wasey, M. A., Russell, L. M., Takahama, S., Liu, S., van Donkelaar, A., Duck, T., Martin, R. V., Zhang, Q., Sun, Y., McKendry, I., Shantz, N. C., and Cubison, M.: Evidence for Asian dust effects from aerosol plume measurements during INTEX-B 2006 near Whistler, BC, Atmos. Chem. Phys. Discuss., 8, 18531-18589, 2008 , http://www.atmos-chem-phys-discuss.net/8/18531/2008/.

Livesey, N. J., Filipiak, M. J., Froidevaux, L., et al.: Validation of Aura Microwave Limb Sounder $\mathrm{O}_{3}$ and $\mathrm{CO}$ observations in the upper troposphere and lower stratosphere, J. Geophys. Res., 113, D15S02, doi:10.1029/2007JD008805, 2008.

Luo, M., Rinsland, C., Fisher, B., et al.: TES carbon monoxide validation with DACOM aircraft measurements during INTEX-B 2006, J. Geophys. Res., 112, D24S48, doi:10.1029/2007JD008803, 2007.

Mao, J., Ren, X., Brune, W. H., Olson, J. R., Crawford, J. H., Fried, A., Huey, L. G., Cohen, R. C., Heikes, B., Singh, H. B., Blake, D. R., Sachse, G. W., Diskin, G. S., Hall, S. R., and Shetter, R. E.: Airborne measurement of $\mathrm{OH}$ reactivity during INTEX-B, Atmos. Chem. Phys., 9, 163-173, 2009, http://www.atmos-chem-phys.net/9/163/2009/.

McKendry, I. G., Macdonald, A M., Leaitch, W. R., van Donkelaar, A., Zhang, Q., Duck, T., and Martin, R. V.: Trans-Pacific dust events observed at Whistler, British Columbia during INTEX-B, Atmos. Chem. Phys. Discuss., 8, 10275-10300, 2008, http://www.atmos-chem-phys-discuss.net/8/10275/2008/.

McNaughton, C. S., Clarke, A. D., Kapustin V., Shinozuka, Y., Howell, S. G., Anderson, B. E., Winstead, E., Dibb, J., Scheuer, E., Cohen, R. C., Wooldridge, P., Perring, A., Huey, L. G., Kim, S., Jimenez, J.L., Dunlea, E.J., DeCarlo, P.F., Wennberg, P. O., Crounse J. D., Weinheimer, A.J., Flocke, F.: Heterogeneous reactions between Asian pollution and dust over the eastern North Pacific, Atmos. Chem. Phys. Discuss., submitted, 2009.

Miller, C. E., Crisp, D., DeCola, P. L., et al.: Precision requirements for space-based $X_{\mathrm{CO} 2}$ data, J. Geophys. Res., 112, D10314, doi:10.1029/2006JD007659, 2007.

Millet, D. B., Jacob, D. J., Custer, T. G., de Gouw, J. A., Goldstein, A. H., Karl, T., Singh, H. B., Sive, B. C., Talbot, R. W., Warneke, C., and Williams, J.: New constraints on terrestrial and oceanic sources of atmospheric methanol, Atmos. Chem. Phys. Discuss., 8, 7609-7655, 2008,

http://www.atmos-chem-phys-discuss.net/8/7609/2008/.
Molina, L. T., Madronich, S., Gaffney, J. S., and Singh, H. B.: Overview of MILAGRO/INTEX-B campaign, IGAC News Letter, 38, 2-15, http://www.igac.noaa.gov, 2008.

Molina, M. J. and Molina, L. T.: 2004 Critical Review: Megacities and atmospheric pollution, J. Air Waste Manage., 54, 644-680, 2004.

Molina, L. T., Kolb, C. E., de Foy, B., Lamb, B. K., Brune, W. H., Jimenez, J. L., Ramos-Villegas, R., Sarmiento, J., ParamoFigueroa, V. H., Cardenas, B., Gutierrez-Avedoy, V., and Molina, M. J.: Air quality in North America's most populous city overview of the MCMA-2003 campaign, Atmos. Chem. Phys., 7, 2447-2473, 2007, http://www.atmos-chem-phys.net/7/2447/2007/.

Nardi, B., Gille, J. C., Barnett, J. J., et al.: Initial validation of ozone measurements from the High Resolution Dynamics Limb Sounder, J. Geophys. Res., 113, D16S36, doi:10.1029/2007JD008837, 2008.

Nassar, R., Logan, J. A., Worden, H. M., et al.: Validation of Tropospheric Emission Spectrometer (TES) nadir ozone profiles using ozonesonde measurements, J. Geophys. Res., 113, D15S17, doi:10.1029/2007JD008819, 2008.

Nowak J. B., Parrish, D. D., Neuman, J. A., et al.: Gas-phase chemical characteristics of Asian emission plumes observed during ITCT 2K2 over the Eastern North Pacific Ocean, J. Geophys. Res., 109, D23S19, doi:10.1029/2003JD004488, 2004.

Oltmans, S. J., Lefohn, A. S., Harris, J. M., et al.: Long-term changes in tropospheric ozone, Atmos. Environ., 40(17), 31563173, 2006.

Olson, J. R., Crawford, J. H., Chen, G., et al.: Testing fast photochemical theory during TRACE-P based on measurements of $\mathrm{OH}, \mathrm{HO}_{2}$, and $\mathrm{CH}_{2} \mathrm{O}$, J. Geophys. Res., 109, D15S10, doi:10.1029/2003JD004278, 2004.

Parrish D. D., Kondo, Y., Cooper, O. R., Brock, C. A., Jaffe, D. A., Trainer, M., Ogawa, T., Hübler, G., Fehsenfeld, F. C.: Intercontinental Transport and Chemical Transformation 2002 (ITCT 2K2) and Pacific Exploration of Asian Continental Emission (PEACE) experiments: An overview of the 2002 winter and spring intensives, J. Geophys. Res., 109, D23S01, doi:10.1029/2004JD004980, 2004.

Peltier, R. E., Hecobian, A. H., Weber, R. J., Stohl, A., Atlas, E. L., Riemer, D. D., Blake, D. R., Apel, E., Campos, T., and Karl, T.: Investigating the sources and atmospheric processing of fine particles from Asia and the Northwestern United States measured during INTEX B, Atmos. Chem. Phys., 8, 1835-1853, 2008, http://www.atmos-chem-phys.net/8/1835/2008/.

Pfister, G., Hess, P. G., Emmons, L. K., Lamarque, J.-F., Wiedinmyer, C., Edwards, D. P., Pétron, G., Gille, J. C., Sachse, G. W.: Quantifying CO emissions from the 2004 Alaskan wildfires using MOPITT CO data, Geophys. Res. Lett., 32, L11809, doi:10.1029/2005GL022995, 2005.

Pierce, R. B., Al-Saadi, J. A., Schaack, T., et al.: Regional Air Quality Modeling System (RAQMS) predictions of the tropospheric ozone budget over East Asia, J. Geophys. Res, 108(D21), 88258835, doi:10.1029/2002JD003176, 2003.

Radke, L. F., Friedli, H. R., Heikes, B. G., Atmospheric mercury over the NE Pacific during spring 2002: Gradients, residence time, upper troposphere lower stratosphere loss, and long-range transport, J. Geophys. Res., 112, D19305, doi:10.1029/2005JD005828, 2007. 
Raper, J. L., Kleb, M. M., Jacob, D. J., Davis, D. D., Newell, R. E., Fuelberg, H. E., Bendura, R. J., Hoell, J. M., and McNeal, R. J.: Pacific Exploratory Mission in the tropical Pacific: PEMTropics B, March-April 1999, J. Geophys. Res., 106, 3240132425, 2001.

Reidmiller, D. R., Jaffe, D. A., Chand, D., Strode, S., Swartzendruber, P., Wolfe, G. M., and Thornton, J. A.: Interannual variability of long-range transport as seen at the Mt. Bachelor Observatory, Atmos. Chem. Phys. Discuss., 8, 16335-16379, 2008, http://www.atmos-chem-phys-discuss.net/8/16335/2008/.

Richards, N., Osterman, G., Browell, E. V., Hair, J., Avery, M. A., and Li, Q. B.: Validation of Tropospheric Emission Spectrometer ozone profiles with aircraft observations during the Intercontinental Chemical Transport Experiment-B, J. Geophys. Res., 113, D16S29, doi:10.1029/2007JD008815, 2008.

Rinsland, C. P., Dufour, G., Boone, C. D., Bernath, P. F., Chiou, L., Coheur, P.-F., Turquety, S., Clerbaux, C.: Satellite boreal measurements over Alaska and Canada during JuneJuly 2004: Simultaneous measurements of upper tropospheric $\mathrm{CO}, \mathrm{C}_{2} \mathrm{H}_{6}, \mathrm{HCN}, \mathrm{CH}_{3} \mathrm{Cl}, \mathrm{CH}_{4}, \mathrm{C}_{2} \mathrm{H}_{2}, \mathrm{CH}_{3} \mathrm{OH}, \mathrm{HCOOH}, \mathrm{OCS}$, and $\mathrm{SF}_{6}$ mixing ratios, Global Biogeochem. Cy., 21, GB3008, doi:10.1029/2006GB002795, 2007.

Santee, M. L., Lambert, A., Read, W. G., Livesey, N. J., et al.: Validation of Aura Microwave Limb Sounder $\mathrm{HNO}_{3}$ Measurements, J. Geophys. Res., 112, D24S40, doi:10.1029/2007JD008721, 2007

Schoeberl, M. R., Douglass, A. R., Hilsenrath, E., et al.: Overview of the EOS Aura Mission, IEEE T. Geosci. Remote, 44(5), 10661074, doi:10.1109/TGRS.2005.861950, 2006.

Shim, C., Li, Q., Luo, M., Kulawik, S., Worden, H., Worden, J., Eldering, A., Diskin, G., Sachse, G., Weinheimer, A., Knapp, D., Montzca, D., Campos, T.: Satellite observations of Mexico City pollution outflow from the Tropospheric Emissions Spectrometer (TES), Atmos. Environ., 43(8), 1540-1547, 2009.

Singh, H. B., Salas, L., Herlth, D., et al.: Reactive nitrogen distribution and partitioning in the North American troposphere and lowermost stratosphere, J. Geophys. Res., 112, D12S04, doi:10.1029/2006JD007664, 2007.

Singh, H. B., Brune, W. H., Crawford, J. H., Jacob, D. J., and Russell, P. B.: Overview of the summer 2004 Intercontinental Chemical Transport Experiment - North America (INTEX-A), J. Geophys. Res., 111, D24S01, doi:10.1029/2006JD007905, 2006.

Stohl, A. (Ed.): Intercontinental Transport of Air Pollution, The Handbook of Environmental Chemistry, Springer-Verlag, Berlin, Germany,vol. 4, 325 pp., 2004.

Stohl, A., Hittenberger, M., and Wotawa, G.: Validation of the Lagrangian particle dispersion model FLEXPART against large scale tracer experiment data, Atmos. Environ., 32, 4245-4264, 1998.

Sun, Y., Zhang, Q., MacDonald, A. M., Hayden, K., Li, S. M., Liggio, J., Liu, P. S. K., Anlauf, K. G., Leaitch, W. R., Cubison, M., Worsnop, D., van Donkelaar, A., and Martin, R. V.: Sizeresolved aerosol chemistry on Whistler Mountain, Canada with a High-Resolution Aerosol Mass Spectrometer during INTEXB, Atmos. Chem. Phys. Discuss., 8, 20749-20798, 2008, http://www.atmos-chem-phys-discuss.net/8/20749/2008/.

Swartzendruber, P. C., Chand, D., Jaffe, D. A., Smith, J., Reidmiller, D., Gratz, L., Keeler, J., Strode, S., Jaeglé, L., and Talbot, R.: Vertical distribution of mercury, CO, ozone, and aerosol scattering coefficient in the Pacific Northwest during the spring 2006 INTEX-B campaign, J. Geophys. Res., 113, D10305, doi:10.1029/2007JD009579, 2008.

Talbot, R., Mao, H., Scheuer, E., Dibb, J., and Avery, M.: Total depletion of $\mathrm{Hg}$ in the upper troposphere - lower stratosphere, Geophys. Res. Lett, 34, L23804, doi:10.1029/2007GL031366, 2007.

Talbot, R., Mao, H., Scheuer, E., Dibb, J., Avery, M., Browell, E., Sachse, G., Vay, S., Blake, D., Huey, G., and Fuelberg, H.: Factors influencing the large-scale distribution of $\mathrm{Hg}^{\circ}$ in the Mexico City area and over the North Pacific, Atmos. Chem. Phys., 8, 2103-2114, 2008, http://www.atmos-chem-phys.net/8/2103/2008/.

Tang, Y., Carmichael, G. R., Seinfeld, J. H., et al.: Threedimensional simulations of inorganic aerosol distributions in East Asia during spring 2001, J. Geophys. Res., 109, D19S23, doi:10.1029/2003JD004201, 2004.

Thompson, A. M., Yorks, J. E., Miller, S. K., Witte, J. C., Dougherty, K. M., Morris, G. A., Baumgardner, D., Ladino, L., and Rappenglck, B.: Tropospheric ozone sources and wave activity over Mexico City and Houston during MILAGRO/Intercontinental Transport Experiment (INTEX-B) Ozonesonde Network Study, 2006 (IONS-06), Atmos. Chem. Phys., 8, 5113-5125, 2008,

http://www.atmos-chem-phys.net/8/5113/2008/.

van Donkelaar, A., Martin, R. V., Leaitch, W. R., Macdonald, A. M., Walker, T. W., Streets, D. G., Zhang, Q., Dunlea, E. J., Jimenez, J. L., Dibb, J. E., Huey, L. G., Weber, R., and Andreae, M. O.: Analysis of aircraft and satellite measurements from the Intercontinental Chemical Transport Experiment (INTEX-B) to quantify long-range transport of East Asian sulfur to Canada, Atmos. Chem. Phys., 8, 2999-3014, 2008,

http://www.atmos-chem-phys.net/8/2999/2008/.

Wolfe, G. M., Thornton, J. A., McNeill, V. F., Jaffe, D. A., Reidmiller, D., Chand, D., Smith, J., Swartzendruber, P., Flocke, F., and Zheng, W.: Influence of trans-Pacific pollution transport on acyl peroxy nitrate abundances and speciation at Mount Bachelor Observatory during INTEX-B, Atmos. Chem. Phys., 7, 53095325, 2007,

http://www.atmos-chem-phys.net/7/5309/2007/.

Zhang, L., Jacob, D. J., Boersma, K. F., Jaffe, D. A., Olson, J. R., Bowman, K. W., Worden, J. R., Thompson, A. M., Avery, M. A., Cohen, R. C., Dibb, J. E., Flocke, F. M., Fuelberg, H. E., Huey, L. G., McMillan, W. W., Singh, H. B., and Weinheimer, A. J.: Transpacific transport of ozone pollution and the effect of recent Asian emission increases on air quality in North America: an integrated analysis using satellite, aircraft, ozonesonde, and surface observations, Atmos. Chem. Phys. Discuss., 8, 8143-8191, 2008 , http://www.atmos-chem-phys-discuss.net/8/8143/2008/.

Zhang, Q., Streets, D. G., Carmichael, G. R., He, K., Huo, H., Kannari, A., Klimont, Z., Park, I., Reddy, S., Fu, J. S., Chen, D., Duan, L., Lei, Y., Wang, L., and Yao, Z.: Asian emissions in 2006 for the NASA INTEX-B mission, Atmos. Chem. Phys. Discuss., 9, 4081-4139, 2009,

http://www.atmos-chem-phys-discuss.net/9/4081/2009/. 